University of Texas at El Paso

\title{
DigitalCommons@UTEP
}

Open Access Theses \& Dissertations

2017-01-01

\section{Active learning effect on the public's perception of anthropogenic global climate change}

Ivy Gisselle Trevizo

University of Texas at El Paso, ivy.trevizo@yahoo.com

Follow this and additional works at: https://digitalcommons.utep.edu/open_etd

Part of the Climate Commons, Education Commons, and the Environmental Indicators and Impact Assessment Commons

\section{Recommended Citation}

Trevizo, Ivy Gisselle, "Active learning effect on the public's perception of anthropogenic global climate change" (2017). Open Access Theses \& Dissertations. 568.

https://digitalcommons.utep.edu/open_etd/568 


\section{ACTIVE LEARNING EFFECT ON THE PUBLIC'S \\ PERCEPTION OF ANTHROPOGENIC \\ GLOBAL CLIMATE CHANGE \\ IVY GISSELLE TREVIZO}

Master's Program in Environmental Science

APPROVED:

Deana D. Pennington, Ph.D., Chair

Laura Serpa, Ph.D.

William Robertson, Ph.D.

Charles Ambler, Ph.D.

Dean of the Graduate School 
Copyright (C)

by

Ivy G. Trevizo

2017 


\section{Dedication}

I would like to dedicate this to my loving husband who not only encouraged me to pursue a Master's degree, but also supported me throughout the journey. His motivation and belief in me led to this accomplishment. I also would like to dedicate this to my dad and mom who have always supported my dreams by teaching me to believe in myself and accomplishing any goal despite the obstacles I faced. 


\title{
ACTIVE LEARNING EFFECT ON THE PUBLIC'S \\ PERCEPTION OF ANTHROPOGENIC \\ GLOBAL CLIMATE CHANGE
}

\author{
by \\ IVY GISSELLE TREVIZO, BS
}

\author{
THESIS \\ Presented to the Faculty of the Graduate School of \\ The University of Texas at El Paso \\ in Partial Fulfillment \\ of the Requirements \\ for the Degree
}

\section{MASTER OF SCIENCE}

Department of Geological Sciences

THE UNIVERSITY OF TEXAS AT EL PASO

December 2017 


\section{Acknowledgements}

The support and knowledge of Dr. Deana Pennington, Dr. Laura Serpa, and Dr. William

Robertson is greatly acknowledged. I would like to especially thank Dr. Pennington for her time,

knowledge and resources. I gratefully acknowledge the assistance of Oscar Ricaud and Luis

Chavira in creating the online interface and the use of Lifemapper. This material is based upon

work supported by the National Science Foundation under Grant No. DBI- 1356707 for the

Transforming Biodiversity Analysis with Landscapes, Automation, and Provenance project. I

would also like to acknowledge the Diana Natalicio Environmental Education Endowment. 


\begin{abstract}
Anthropogenic, or human-caused global climate change has been debated for many years among the public despite the growing evidence that there is scientific consensus on this topic. A gap has been discovered between scientific evidence of increasing temperatures and the public's perception on climate change. This gap has been hypothesized to come from the method in which the scientific community represents scientific evidence. The goal of this study was to determine if active learning techniques around local and regional climate change and climate change impacts changes the awareness, perception, and behavioral intentions of different segments of the public. The study used a quantitative component involving online active learning bounded by pre- and post-surveys. A pre-survey was given to all participants, which included questions on their initial awareness, perceptions, and behavioral intentions regarding global climate change. After individuals explored climate data they were prompted to fill out a post-survey, which revealed how these activities had changed their perception on anthropogenic global climate change. Results were consistent throughout in that there was no statistically significant change in the post-activity scores when providing local climate change impacts in the form of a hands-on activity. No statistically significant correlation was found between the independent variables (gender, ethnicity, political view, and education level) and participants' change in concern from the pre- and post-activity results. The study found that although there was no statistically significant change in concern level for participants based on their political views, participants who associated as conservative had a higher increase in level of concern (36.8\%), becoming more alarmed, than liberals who became more alarmed (13.3\%). In contrast, more liberals had a decrease in concern $(33.3 \%)$, becoming less alarmed, than conservatives who became less concerned $(21.1 \%)$. These results indicate that this curriculum (looking at data for themselves) was useful for increasing concern of AGW of conservatives while decreasing concern of liberals. This method of communicating to the public caused individuals to move away from the extremes of their political view.
\end{abstract}




\section{Table of Contents}

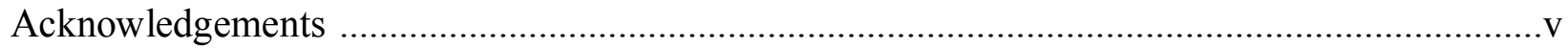

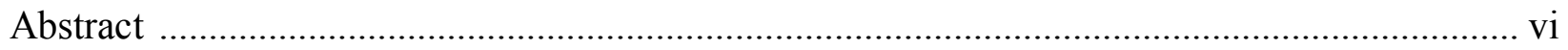

Table of Contents ........................................................................................................ vii

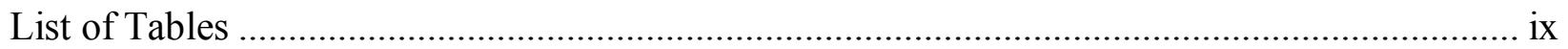

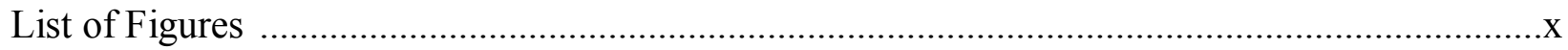

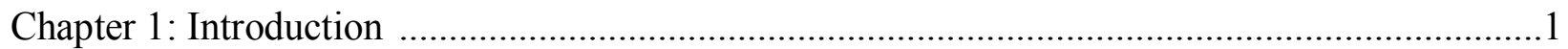

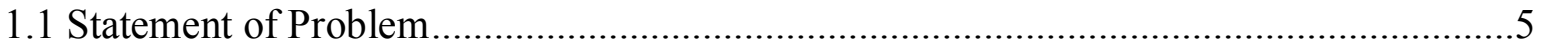

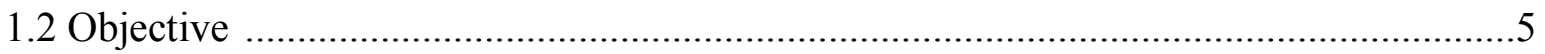

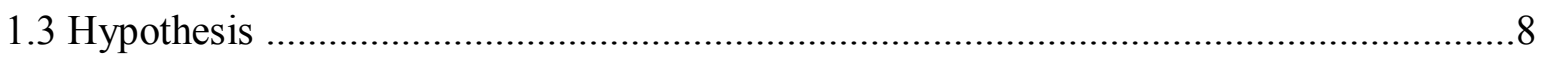

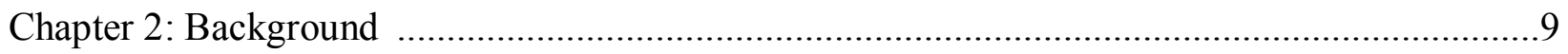

2.1 Studies of worldview and beliefs about climate change ..........................................

2.2 Climate change reconstrustions and projections ....................................................13

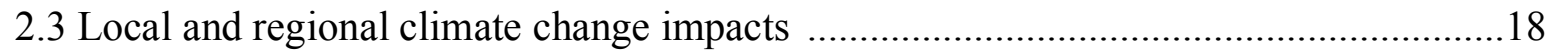

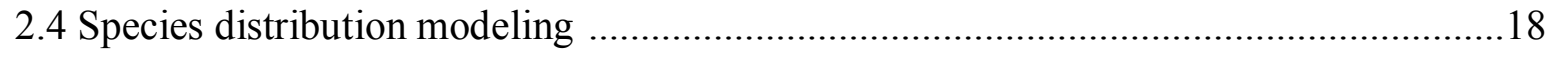

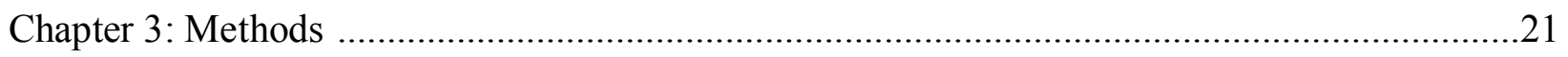

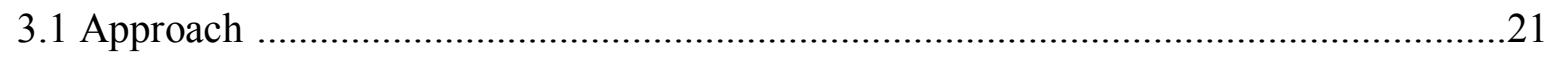

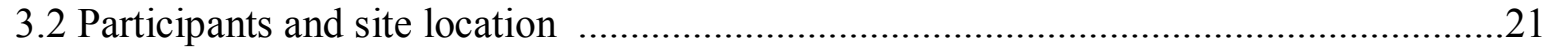

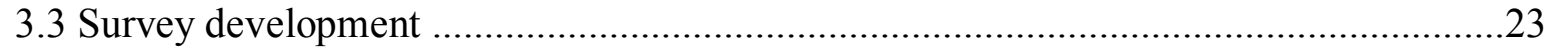

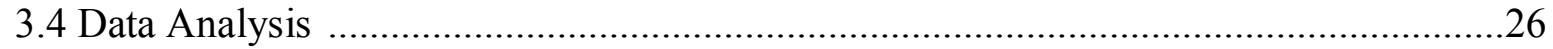

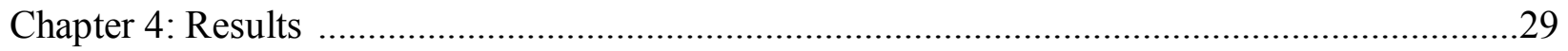

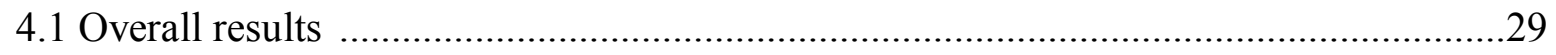

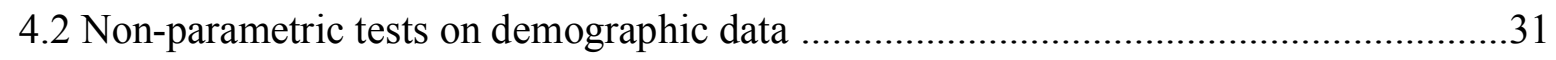

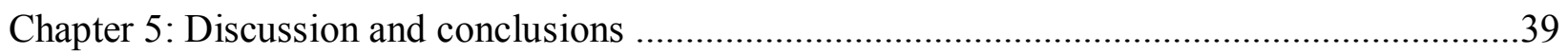

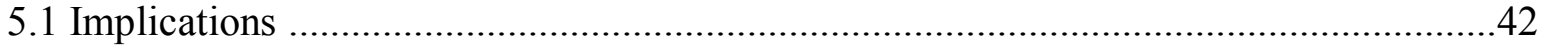

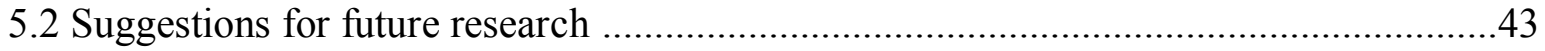




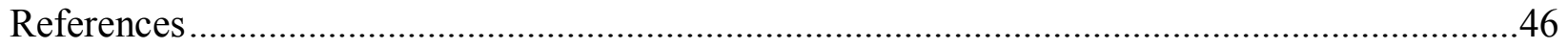

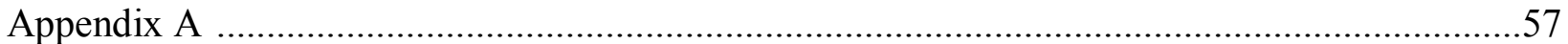

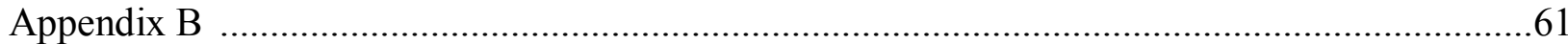

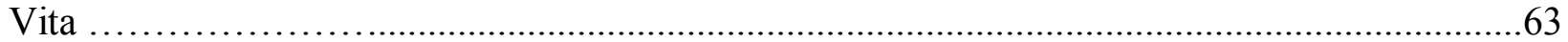




\section{List of Tables}

Table 3.1: Event where survey participants were recurited ................................................ 22

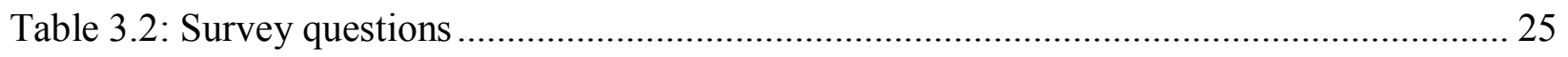

Table 3.3: Change in concern level based on score difference .............................................. 27

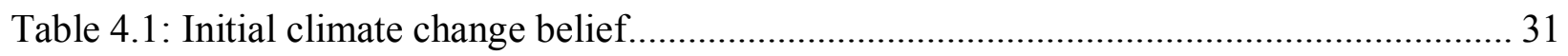

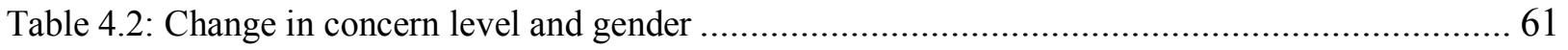

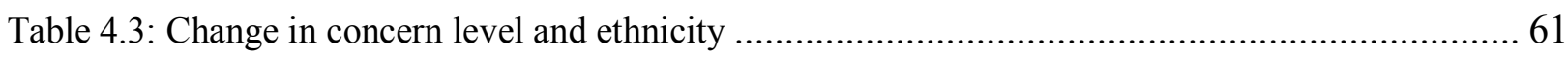

Table 4.4:Change in concern level by gender and ethnicity .................................................61

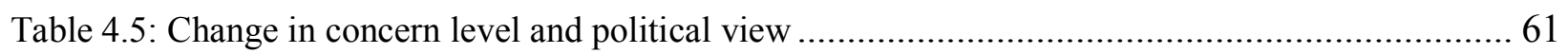

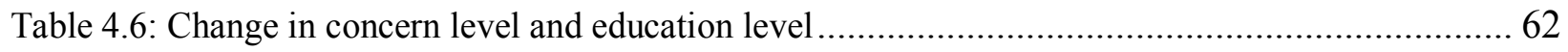




\section{List of Figures}

Figure 2.1: Projected changes in annual average temperatures ................................................ 14

Figure 2.2: Observed globally averaged land and ocean surface temperature anomalies ............ 16

Figure 2.3: Annual global anthropogenic carbon dioxide $\left(\mathrm{CO}_{2}\right)$ emissions ............................... 17

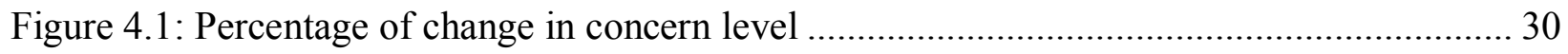

Figure 4.2: Paire t-test: Concern of climate change …………….............................................. 30

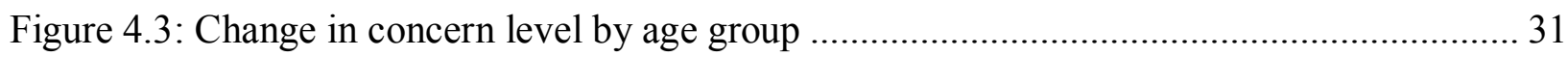

Figure 4.4: Association of change in concern and age ......................................................... 32

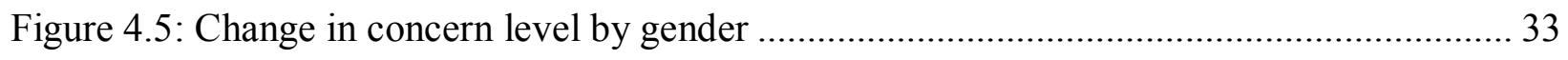

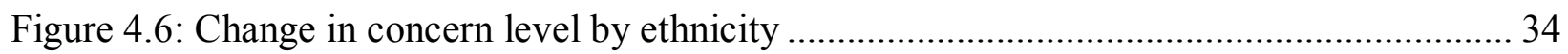

Figure 4.7: Change in concern level by gender and ethnicity................................................. 35

Figure 4.8: Change in concern level by political view .............................................................. 36

Figure 4.9: Change in concern level by education level ............................................................. 37

Figure 4.10: Association of change in concern and education level .......................................... 38 


\section{Chapter 1: Introduction}

Anthropogenic or human-caused global climate change remains a topic of great debate among the public even though there exists a scientific consensus that the Earth's global average temperature has increased, and that much of this increase is due to increased emissions of greenhouse gases such as carbon caused by burning of fossil fuels (Bedford, 2010; Bedford \& Cook, 2013; USGCRP, 2017; Wuebbles et al., 2017). The Intergovernmental Panel on Climate Change (IPCC) and U.S. Global Change Research Program (USGCRP) emphasized that climate change is predominantly anthropogenic and that the damage caused by global warming will most likely be irreversible if no action is taken globally (IPCC, 2013; Shi et al, 2015; USGCRP, 2017; Wuebbles et al., 2017). Since the beginning of the twentieth century there has been an increase in temperatures of $1.3^{\circ} \mathrm{F}$ to $1.9^{\circ} \mathrm{F}$ and temperatures in the United States are predicted to increase by $7^{\circ} \mathrm{F}$ to $9^{\circ} \mathrm{F}$ by 2100 (Melillo et al., 2014; Egan \& Mullin, 2017). Hence, it is imperative that the public be convinced of the reality and consequences of anthropogenic global warming.

Several terms have been interchangeably used to describe the changing climate. Climate change is a term used to describe any change in Earth's climate over time including warming, cooling, or getting wetter or drier (IPCC, 2007; Bedford, 2010). Climate change involves more than warming, has no spatial reference, and can refer to events that are global, regional or local in extent (Bedford, 2010). Global warming, on the other hand, explicitly involves a global scale, refers to increasing average temperatures while not considering other climate changes, and does not identify a particular cause of these changes. Another term commonly used is anthropogenic global warming (AGW), which refers to an increase in temperature that is human-caused (Bedford, 2010). Although AGW is an increase of average temperature at a global scale, not all 
places on Earth experience the same change. Therefore, some places on Earth will experience cooling and others may become wetter. This study focuses on public perception of AGW.

A wide variety of scientific observations provide evidence that global temperatures are rising. Analysis of global, long-term temperature observations have found that 2014 was the warmest year on record and the last three years have been the warmest years recorded globally (USGCRP, 2017 p 10; 13). Findings show that sixteen of the warmest years that have been recorded globally occurred in the last seventeen years, excluding 1988 (USGCRP, 2017, p 13). The temperature of the sea surface has increased (IPCC, $2014 \mathrm{p} 40$ ), resulting in bleaching of coral reefs worldwide (IPCC, 2014 p 51); more than a quarter of the $\mathrm{CO}_{2}$ emitted into the atmosphere has been absorbed by the ocean making it more acidic (USGCRP, 2017 p 28). Glaciers are receding (IPCC, 2014 p 42) and the polar ice caps are melting (IPCC, 2014 p 42) causing coastal flooding as the ocean rises (USCCRP, 2017 p 27). Global sea level has risen by 7 inches since the 1900s and is expected to continue rising by 1-4 feet by 2100 (USGCR, $2017 \mathrm{p}$ 10). Heavy rainfall is expected to increase in intensity and frequency; heatwaves have become more frequent since 1960 ; and temperatures will rise by $2.5^{\circ} \mathrm{F}$ over the next few decades $(2021$ 2050) (USGCR, 2017, p 10-11). In a more recent study by Hsiang et al. (2017) it was found that rising temperatures will have detrimental effect on the country's economics and there will be a rise in energy costs and death tolls related to heat waves. Already extreme events have cost the United States more than \$1.1 trillion since 1980 (USGCRP, 2017; Wuebbles et al., 2017).

Warming will be occurring throughout the United States, but the southern states will suffer more due to the rising temperatures, including Texas (Plumer \& Popovich, 2017; Hsiang et al., 2017).

The increase in temperature is correlated with increases in atmospheric carbon dioxide. Carbon dioxide concentrations of no more than 300 parts per million have been recorded from 
420, 000-year-old ice cores (Weber \& Stern, 2011). In 1959, the observatory in Mauna Loa, Hawaii measured atmospheric carbon dioxide at high levels of 315 parts per million and by the end of the 1970s carbon dioxide levels reached 335 parts per million (Hecht \& Tirpak, 1995; Weber \& Stern, 2011). More recently the USGCRP, (2017) has found that global atmospheric carbon dioxide concentration has now exceeded 400 parts per million. This discovery in 1970 led Congress to pass the Global Climate Act in 1987 to combat global warming and in 1990 a national research program was established by the Global Change Research Act to study global environmental change, its effects, and possible responses (Weber \& Stern, 2011). Since then, scientists have increased their understanding of climate change over the past 150 years by accumulating observational data, testing and refining hypotheses, construction of theories and models to synthesize knowledge, and testing of these theories and models (National Research Council, 2010; Weber \& Stern, 2011).

In addition, an analysis by Oreskes (2004) of 928 abstracts from peer-reviewed scientific articles (published between 1993 and 2003) found strong agreement among the scientific community that warming is occurring largely due to anthropogenic emissions of greenhouse gases, which include carbon dioxide and methane, as well as the burning of fossil fuels and landcover changes. Oreskes (2004) also found that among all the authors there were no disagreement with the consensus and none of the abstracts argued that current climate change is natural. The study also reported that major scientific bodies such as the IPCC, National Academy of Sciences, American Meteorological Society and the American Geophysical Union had recently issued statements that agreed on the evidence that human activity is enhancing climate change (Oreskes, 2004). Recently the USGCRP 2017 assessment, based on extensive evidence, concluded that human activity (human contribution of $93 \%$ to $123 \%$ ) is the dominant (with a high confidence) 
and extremely likely cause of warming; observed warming is especially due to emissions of greenhouse gases (USGCRP, 2017 p 10; 114). Another study (Weber \& Stern, 2011), used an IPCC assessment report from 2007 and various independent assessments and found that 97\%$98 \%$ of active and prominent climate scientists who were signatories of major public statements were endorsers of climate change. Cook et al. (2013) reviewed abstracts from 1991 to 2001 that used words "global climate change" and "global warming" and found that $97 \%$ of the papers recognized that the Earth's average temperature is increasing due to greenhouse gas emissions. In a recent synthesis of findings from six independent studies of the scientific literature on climate change, Cook et al. (2016) reported a 97\% consensus among climate science experts that the dominant cause of observed warming is human activities, and that the National Academies of Science from 80 countries have issued statements endorsing this position. Hence, strong consensus among scientists regarding human-induced climate change has existed for at least a decade.

Although it is possible to find peer-reviewed publications that reject this scientific consensus among the scientific community, these only represent a small portion of the humaninduced climate change publications (Cook et al., 2013). Several of the studies that published papers that claim the scientific consensus is not real have been strongly challenged and found to be flawed (Cook \& Jacobs, 2014; Abraham et al., 2014).

\subsection{Statement of Problem}

The public understanding of this issue is inconsistent with the scientific consensus; a misconception by the public is that there is disagreement on the reality and causes of climate change among scientists. This gap has been termed the "consensus gap" which leads to a lower 
belief on the reality of climate change and results in a lack of support for the policies to mitigate the change (Cook et al., 2013; Cook \& Jacobs, 2014). A survey by Kohut et al. (2009) revealed that three-quarters of people (76\%) think climate change is anthropogenic and believe most scientists agree. Of those who believe warming is due to anthropogenic atmospheric changes, $41 \%$ think there is no scientific consensus. More recently, Leiserowitz et al. (2014) found a misunderstanding of scientific consensus among American adults: only $42 \%$ believe that most of the scientific community thought global warming is occurring, $33 \%$ voiced that there is much disagreement among the scientific community whether global warming is occurring, $20 \%$ perceived themselves to not be educated enough to respond, and $6 \%$ believe that most of the scientific community does not think global warming is occurring.

Awareness has steadily increased over the years with 4 in 5 Americans professing that they understand the issue when it comes to climate change (Bowman et al., 2016; Egan \& Mullin, 2017). Although there has been an increase in awareness by the public this has not yet translated into factual knowledge as less than half of Americans do not acknowledge that scientists agree that climate change is occurring (Egan \& Mullin, 2017).

\subsection{Objective}

The aforementioned studies focused on tailoring messaging and content to different types of audiences in surveys. This study tried to address the issue of lack of knowledge by providing an active learning activity, in hopes that giving the public an opportunity to interact with climate data themselves would change their concern about AGW. There are many opportunities for outreach that involve direct engagement with the public and hands-on activities. Such activities are referred to as "active learning." Active learning can be defined generally as any kind of 
instructional method that is used to engage the students in the learning process (Prince, 2004). In other words, active learning requires the student to accomplish meaningful activities and to think about what they are learning (Bonwell \& Eison, 1991; Prince, 2004). Active learning characteristics include: 1) the student is involved in more than just listening, 2) more emphasis is placed on developing of a students' skills, 3) students are involved in higher-ordered thinking which include analysis, synthesis and evaluation, 4) emphasis is placed on the exploration of the students' attitudes and values (Bonwell \& Eison, 1991).

A study by Redish et al. (1991) showed that improvement in learning gains was attributed to the nature of active engagement and not due to the extra time spent on a given topic. Prince (2004) disclosed that Redish et al. (1991), along with other studies, (Hake et al. 1998; Laws et al. 1999) when taken together provided significant support for active engagement techniques. These methods particularly support addressing students' fundamental misconceptions.

Constructivism is a theory which is defined by Naylor \& Keogh (1999) as learning that involves an active process where learners can construct meaning by connecting the new ideas they have learned to their existing knowledge (Jones \& Araje, 2002). A known philosopher, Ernst von Glaserfeld stated, regarding radical constructivism, that constructivism can be a set of beliefs that provides a model of cognition which in turn leads to a method of teaching and allows the students to become an active learner (von Glaserfeld, 1994; Aulls \& Shore, 2008).

Constructivism informs the student about learning and gives them no choice but to interpret reality. This theory also allows students to be active participants in creating meaning from what they are learning and to perceive learning as initiated by understanding (Aulls \& Shore, 2008). Jerome Bruner, throughout his studies also found that "learners are responsible for the 
construction of their own knowledge and understanding to an unanticipated degree" (Olson \& Bailey, 2014).

One model based on constructivism is the "5 E's" approach which capitalizes on handson activities and was therefore used for this study (Carr et al., 2007). The 5 E's of the model are engage, explore, explain, elaborate and evaluate. In the engage stage the instructor uses an engagement activity that connects past and present learning experiences which helps the learner participate in their own learning process (Carr et al., 2007). The instructor's role in this stage is to create interest, raise a question, and generate curiosity. A very important part of engagement is the opportunity for the instructor to identify any misconceptions the learner may have. The explore and explain stages both involve the guidance of the instructor. In explore stage the learners investigate a phenomenon and "arrive at a common understanding of certain concepts, process or skills" and the instructor provides time for the learner to work through some problems. In the explain stage, learners begin to demonstrate conceptual understanding or behaviors by listening and trying to comprehend the explanations given by the instructor (Carr et al., 2007). In this stage, the learner begins to not only organize the evidence-based statements, but they also start to use academic language of science (Carr et al., 2007). The elaborate stage consists of the instructor monitoring and facilitating discussions that will challenge the learner and the evaluate phase is where learners are assessed by the teacher or by themselves throughout the other stages (Carr et al., 2007).

The goal of this study was to determine if active learning based on the 5Es model employed around local and regional climate change impacts, changes the awareness, perception, and behavioral intentions of different segments of the public. This research involved developing an interactive activity that allowed adults to use scientific inquiry to interpret data that displayed 
how climate change is expected to affect local and regional temperature and precipitation, and how those changes may impact water in the region, as well as local and regional species and ecosystems.

\subsection{Hypotheses}

Based on past studies, predictions were made that results would vary considerably by:

- Age, with older participants more likely to be dismissive;

- Gender, with women more likely to be alarmed;

- Race, with Hispanics more likely to be alarmed;

- Political View, with Liberals more likely to be alarmed.

Other predictions made included changes between the pre- and post-surveys would be more pronounced for those who were classified initially as dismissive or uncommitted, and less pronounced for those who were classified initially as alarmed. The project collected and analyzed data regarding how the perception of the public on anthropogenic global climate change had changed during the active learning activity using a pre-survey and post-survey. 


\section{Chapter 2: Background}

\subsection{Studies of worldview and beliefs about climate change}

Although some articles that are related to this study have already been discussed in the preceding section, a brief review of other related research is necessary. While the focus of this study is to determine if active learning has an impact on individuals and their awareness of climate change other studies have focused on an individuals' worldview and preconceptions of climate change. This literature review will cover three sections: first, the importance of an individuals' preconception of the scientific consensus on climate change; second, how the knowledge of scientific education affects the individuals' worldview; and third, what attempts have been made to close the gap between a persons' worldview and adopting accurate scientific mental models.

In two studies by Lewandowsky et al. (2013), the authors examined how the perception of scientific consensus interacts with a persons' worldview, which has been found to be the primary obstacle to acceptance of AGW, and in turn leads to a decline in the public concern. The first study focused on whether scientific consensus contributes to the acceptance of diverse scientific facts- from HIV/AIDs to AGW. This study found that perceived consensus was related to the acceptance of scientific fact, but found the relationship was not unique to AGW but rather was the same for other scientific issues. The second study included two groups, a control group and a test group that was provided information highlighting a 97\% consensus among climate scientists. Participants in the latter group were more willing to attribute long-term climate change to human-causes and accept that human carbon dioxide emissions were the cause when consensus among the scientific community was emphasized. In addition, Schuldt $\&$ Pearson (2016) ran a logistic regression analysis on race differences and found that Whites perceived a 
higher scientific consensus than non-Whites, but overall, along with recent studies, found that perceived scientific consensus was a strong predictor (both non-Whites and Whites) for mitigation efforts (Ding el al., 2015; van der Linden et al., 2015).

Research in science education shows that an individuals' preconception that conflicts with their scientific understanding makes it difficult to create new mental models that are scientifically accurate (National Research Council, 2005; Werner \& Stern, 2011). The conflict of misconception may be caused in part by agnotology which was coined by science historian Robert Proctor (Proctor, 2008; Bedford, 2010). Agnotology is culturally induced ignorance or doubt, sometimes brought about through inaccurate or misleading data, document suppression, or other forms of misinformation in the popular media. Studies have found that misconceptions are very difficult to remove, but one effective way to combat this is through refutations, which were found to explicitly address climate misconceptions and climate misinformation to improve a persons' climate literacy (Muller et al., 2008; Kowalski \& Taylor, 2009; Tippett, 2010; Cook et al., 2014). The study found that using a two-channel science communication that combined information content and cultural meanings was effective for public outreach (Cook et al., 2014).

In another study, Shi et al. (2015) conducted a mail survey in Switzerland that was used to examine what impact climate-change-relevant knowledge had on the publics' concern for climate change when controlling for cultural worldviews. The study focused on the question of whether scientific knowledge is significant for explaining the concern people have for climate change, including their worldview. The authors focused on four subscales of climate-changerelated knowledge: physical knowledge, such as, "burning oil, among other things, produces CO2"; causal knowledge, such as, "climate change is mainly caused by human activities"; action-related knowledge, for example, "a large part of the Co2 emission in Switzerland is 
caused by the transport sector"; and result-related knowledge, such as, "for the next few decades, the majority of climate scientists expect a cooling down of the climate" (Shi et al., 2015).

The results suggested that an individual is motivated to change behavior if they have more knowledge about climate-friendly behaviors and less likely to change behaviors with knowledge about negative consequences of climate change. Shi et al. (2015) concluded that risk communication should focus on causal knowledge (which was positively related to a concern for climate change), emphasizing consequences that are more related to individual lifestyles rather than communicating uncontrollable consequences.

Hine et al. (2016) studied public response to different types of messaging about climate change and found that public perceptions and concerns could be organized into three distinct segments including dismissive, uncommitted and alarmed. Results indicated that participants who were dismissive were more prone to change their beliefs and actions towards climate adaptation when climate change messaging emphasized local impacts. All three segments of participants showed increased motivation for climate change adaptation when content provided specific advice for adaptation.

In a related study, Evans \& Lawrence (2014) found that participants had a stronger will to take part in climate change mitigation when they were given a scenario that focused on adaptation measures based on local climate effects rather than those that were more general climate effects. Evans \& Lawrence (2014) focused on how to deliver the correct data to the public and find a way that would communicate this data with the most impact.

In a recent study, Akerlof et al. (2015), found that vulnerable groups are more concerned about climate risks and feel more threatened by climate change, including people of color. Hispanics have been found to be the most concerned for climate change and willing to say that 
the government should regulate greenhouse gas emissions, according to the Washington PostABC News Poll from 2014. Non-Whites are more prone to care about the environment because often time they are more "directly affected by the negative effects of climate change" (Schuldt \& Pearson, 2016, p 500). Schuldt \& Pearson (2016) also found that political association is a stronger predictor for personal existence belief, likelihood of perceiving a scientific consensus, and support for policy aimed at reducing greenhouse gas emissions among Whites than nonWhites. When it comes to White conservative males, McCright \& Dunlap (2011) found that this group has a higher level of denial of climate change than other groups of adults.

In another study, Marquart-Pyatt et al. (2011) found that adults who associate as a liberal or Democrat have a positive concern for climate change with higher education attainment. The opposite was found with adults who associate as conservative or Republican, they have a negative concern for climate change with higher education attainment (Marquart-Pyatt et al., 2011; Egan \& Mullin, 2017). In a related study, Unsworth \& Fielding (2014) found that adults whose political association was salient provided momentarily less support for climate change policies and their own stance on this issue was aligned more with their political identity.

Scientific consensus on climate change has been established extensively through several studies and shown to influence the publics' perception of AGW. The studies previously described are related to this proposal because they provide details on the most effective way to change the publics' awareness, perception and behavior on AGW, which is the focus of this study. 


\subsection{Climate change reconstructions and projections}

The USGCRP was established in 1989 by the Presidential Initiative to "assist the Nation and the world to understand, assess, predict, and respond to human-induced and natural processes of global change" (About USGCRP, n.d.). In constitution with the White House officials and the Subcommittee on Global Change Research, the USGCRP Executive Director "ensure that the Program meets all mandated requirements" (About USGCRP, n.d.). The USGCRP compromises of 13 agencies that conduct research on global change and its impacts on society (About USGCRP, n.d.). The primary vehicles for implementing and coordinating global change research activities are Interagency Working Groups, who address “major components of the Earth's environmental and human systems" (About USGCRP, n.d.).

The USGCRP Fourth National Climate Assessment recently reported that the period between 1901-2016 has been the warmest in history with record-breaking and climate-related weather extremes in the last few years. Human-activity is the cause for this observed warming since the mid-20the century and in addition to warming, "other aspects of global climate are changing" (USGCRP, 2017 p 10). Examples of these changes have been documented by many studies conducted by researchers and include changes in surface temperatures, atmospheric temperatures and oceanic temperatures; melting glaciers; shrinking sea ice and snow cover; rising sea levels (risen 7-8 inches since 1900); and ocean acidification (USGCRP, 2017). 
Figure 2.1: Projected changes in annual average temperatures

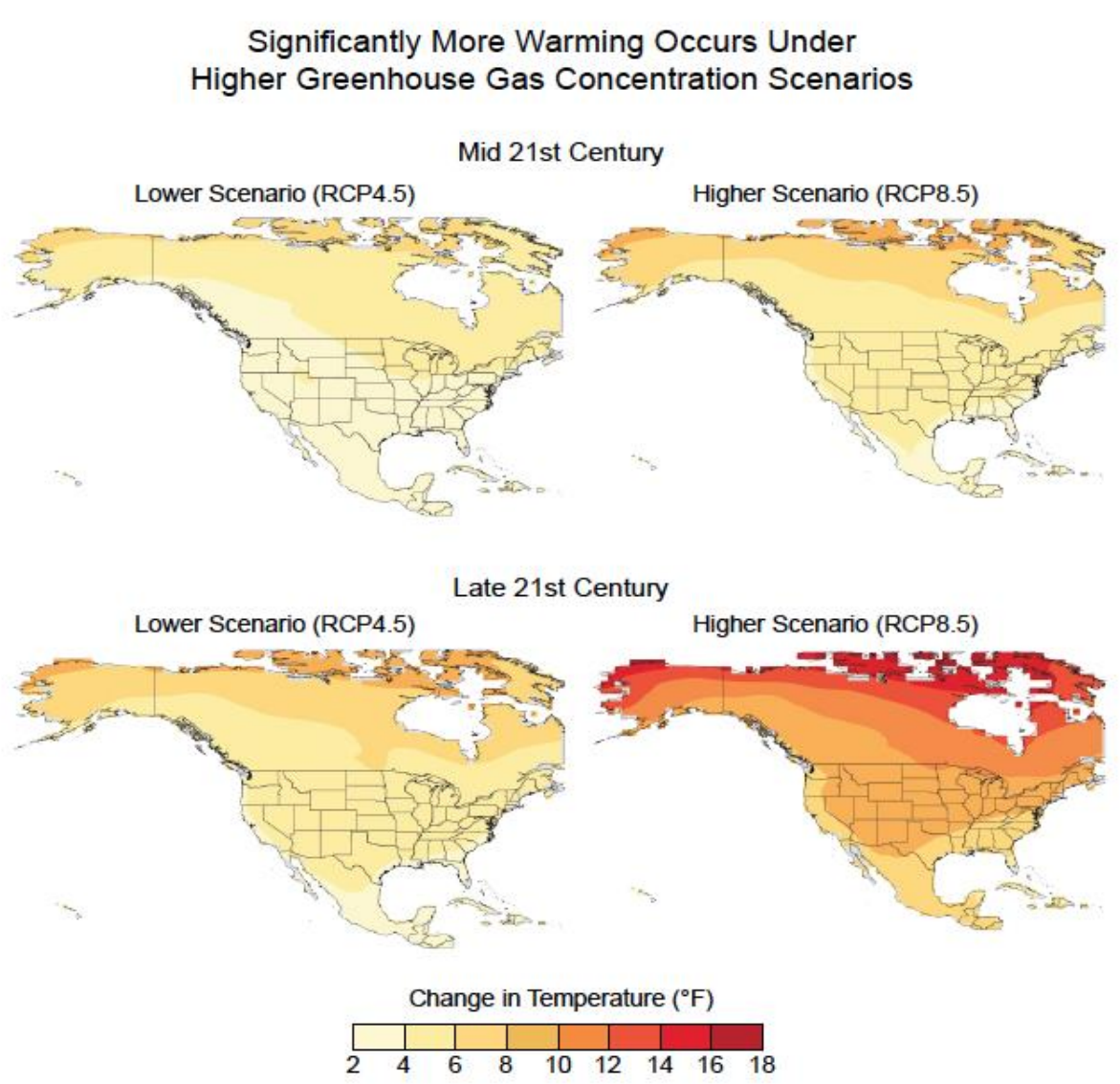

Maps showing projected changes in annual average temperatures for two future pathways for mid and late $21^{\text {st }}$ century. The changes in the maps are the differences between the average projected temperatures for the two scenarios (mid-century (2036-2065) and late-century (2070-2099)) and the average projected temperatures observed for the near-present (1976-2005). (Figure ES.4 in USGCRP Fourth National Climate Assessment, Volume I, p 18).

The IPCC is a leading international body that assesses the most recent scientific information that is produced worldwide relevant to the understanding on the topic of climate change (IPCC, 2013). The IPCC does not conduct any research or monitor climate related data but rather focuses on the review of this scientific information as an essential part that allows for an objective and complete assessment. The IPCC also reflects a range of views and thousands of scientists from all over the world who contribute to this work (IPCC, 2013). 
The IPCC's Fifth Assessment Report in 2015 reported observed changes in the climate system as follows: "human influence on the climate system is clear, and recent anthropogenic emissions of green-house gases are highest in history" (IPCC, 2014 p 2). These changes on the climate system have led to an impact on not only humans, but also on natural systems. The last three decades have been found to be successively warmer than any decades since 1850 leading to the warmest 30-year period (1983-2012) in the last 1400 years in the Northern Hemisphere. Figure 1 shows that over the period of 1880 to 2012, the globally averaged combined land and ocean surface temperature data (calculated with a linear trend) shows a warming of $0.82{ }^{\circ} \mathrm{C}(0.65$ to $\left.1.06^{\circ} \mathrm{C}\right)(\mathrm{IPCC}, 2014)$.

The causes of climate change indicate anthropogenic greenhouse gas emissions are higher than ever, have increased since the pre-industrial era, and have been driven largely by population and economic growth. Figure 2 shows the increase of global anthropogenic $\mathrm{CO}_{2}$ emissions since 1970. Cumulative $\mathrm{CO}_{2}$ emissions have tripled from fossil fuel combustion, cement production and flaring and have increased by $40 \%$ from forestry and other land use. Cumulative anthropogenic $\mathrm{CO}_{2}$ emissions were $2040 \pm 310$ gigatonnes of $\mathrm{CO}_{2}\left(\mathrm{GtCO}_{2}\right)$ between

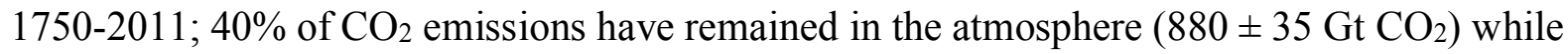
$30 \%$ have been absorbed by the ocean. The IPCC reports with high confidence that half of the anthropogenic $\mathrm{CO}_{2}$ emissions occurred in the last 40 years. 
Figure 2.2 Observed globally averaged land and ocean surface temperature anomalies

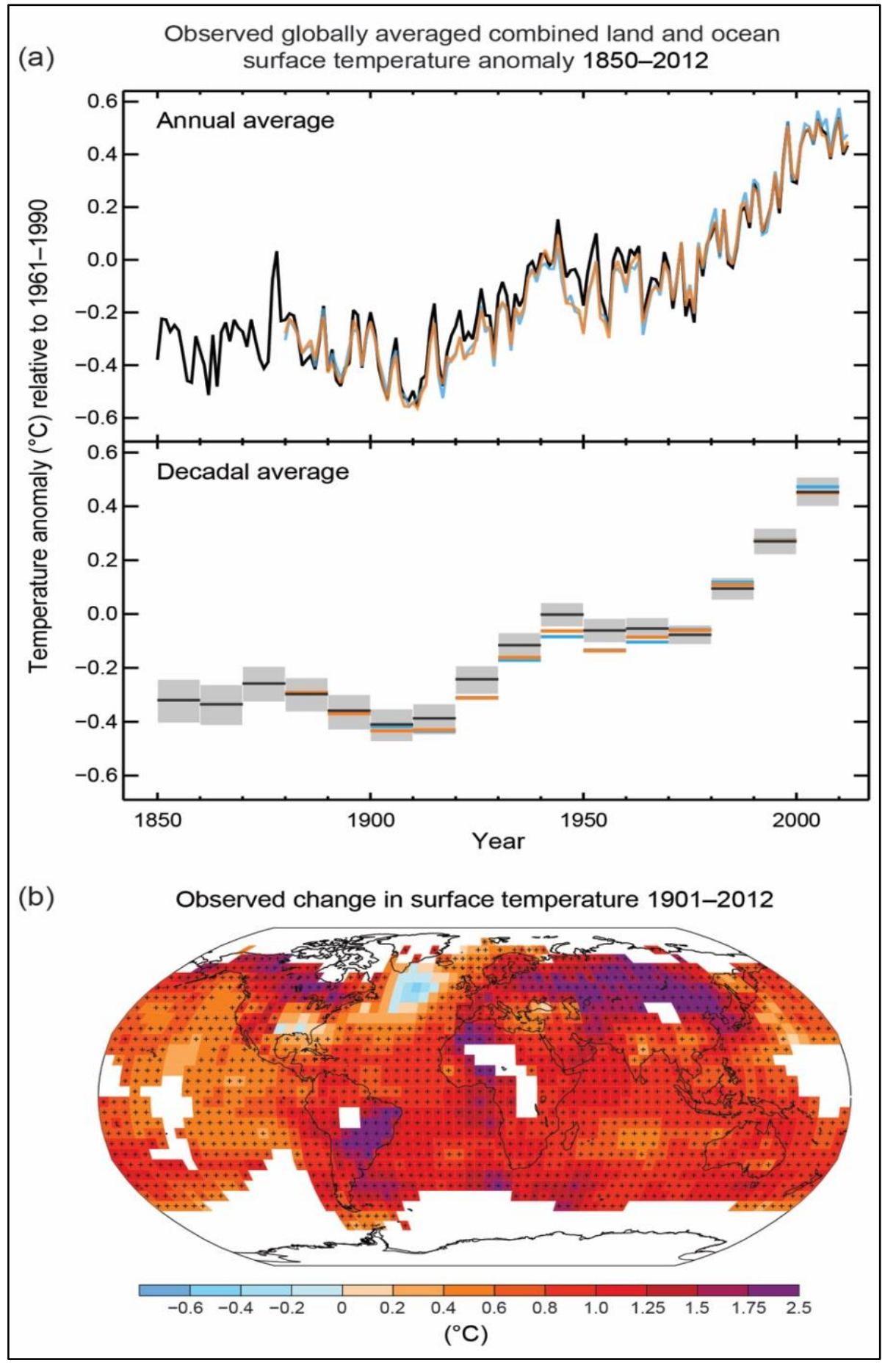

(a) Observed globally averaged land and ocean surface temperatures anomalies combined along with decadal uncertainty for one data set in lower half of graph (shaded in grey). (Figure 1.1a of IPCC Fifth Assessment Report 2015. Working Group 1 Figure SPM.1, p 4, IPCC, Switzerland). 
Figure 2.3 Annual global anthropogenic carbon dioxide $\left(\mathrm{CO}_{2}\right)$ emissions

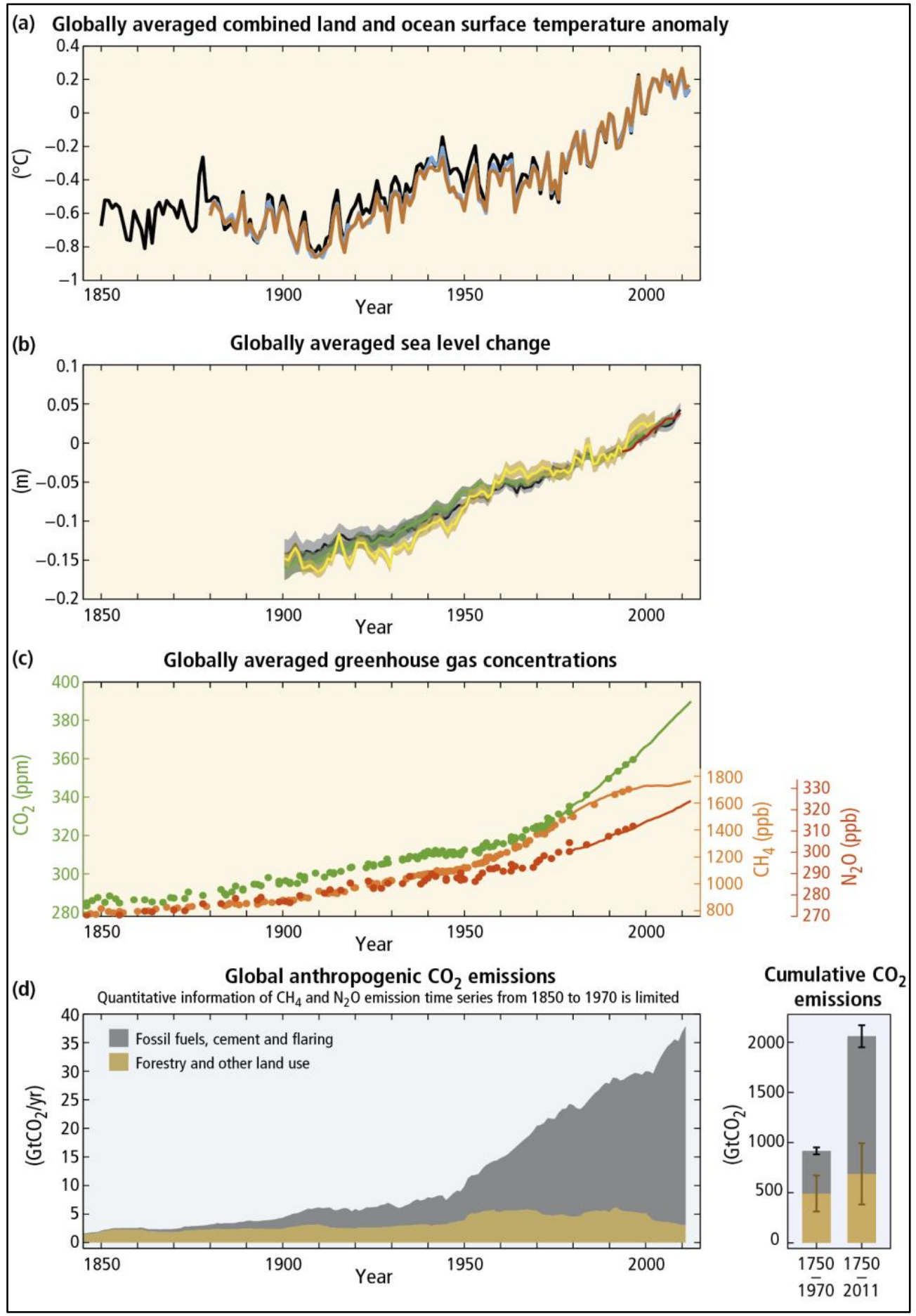

(d) Annual global anthropogenic carbon dioxide $\left(\mathrm{CO}_{2}\right)$ emissions (gigatonne of $\mathrm{CO}_{2}$ - equivalent per year) from 1750 to 2011. Cumulative emissions are shown on the right side as bars and whiskers with uncertainties (IPCC Fifth Assessment Report 2015, Synthesis Report, Figure SPM.1, p 3, IPCC, Switzerland) 


\subsection{Local and regional climate change impacts}

As temperatures increase due to climate change, there will be many changes that are foreseen for the Southwestern US. A study by Routson et al. (2011) suggested that severe drought conditions with a warmer and drier future can be anticipated. This suggestion was based off a new tree-ring record that was collected from a living bristlecone pine (Pinus aristata) that was from the headwaters region in the Rio Grande River. In this record, they found unusual dryness in a multi-century period from 1 to $400 \mathrm{AD}$ including a megadrought from the $2^{\text {nd }}$ century that lasted almost five decades. The drought was more severe than during the medieval period megadroughts known in this region. Their findings suggested the Southwest should anticipate similar drought conditions (Routson et al., 2011).

Ault et al. (2012) suggested that global climate models underestimate the risk for future drought because they do not account for hydroclimatic fluctuations that instrumental and paleoclimate data indicate are multidecadal to multicentury. To assess the risk of persistent droughts, Ault et al. (2012) developed methods that combined paleoclimate information with climate model projections and found the risk for megadroughts in the Southwestern U.S. to be at least $80 \%$ and higher than $90 \%$ in certain areas.

\subsection{Species distribution modeling}

Expected changes in drought and water availability have profound implications for an array of human and environmental processes, including the distribution of species native to the area. Species distribution models (SDM) are an analytical technique used to estimate the environmental conditions where there are known occurrences of a species and compare those conditions at other sites where that species could potentially exist (Hijmans \& Elith 2016). 
SDMs can be used to predict the location of plant and animal species in geographic space that is based on a mathematical representation of the specie's requirements. SDMs can determine the habitat of species that are rare or threatened and can model the potential spread of an invasive species (Hollander, 2013). The SDMs are also useful for creating predictions of suitable habitat for species under future climate conditions, supposing that a specie's habitat will migrate in geographic space due to the change in climate (Hollander, 2013). There are several steps that are taken to create an SDM: 1) collecting the locations where species are known to occur; 2) obtaining environmental variables from spatial databases based on the selected locations; 3 ) fitting environmental variables to a model at each occurrence point; and 4) predicting the variable of interest across the chosen region under current, past or future climate conditions (Hijmans \& Elith, 2016). This approach, therefore, can be used to analyze potential changes in local and regional flora and fauna as a result of changing climate and water resources.

A notable SDM software called Lifemapper (http://lifemapper.org), has been developed by the University of Kansas. Lifemapper combines climate change data with species occurrence data derived from natural museum specimens around the world, and generates data sets of the past, present, and future distribution of species. The model is run automatically each month for every species with sufficient information and the results are cached. More accurate analyses can be conducted as needed. This model is available through a web portal that can be accessed by any user and allows them to browse, download, and manipulate the data and models. An interface to the Lifemapper cache was created that accessed the data for species native to the Middle Rio Grande region. This was embedded in an online curriculum that allowed users to participate in a hands-on activity using the cache of information. Users had the opportunity to 
browse the maps created by Lifemapper for whichever local and regional species they were interested in.

This project was built on prior educational research conducted by the SPECIES (Students Predicting the Effects of Climate In Ecosystems) project, created by the University of Michigan in collaboration with the Lifemapper project. The SPECIES interface consisted of a fourteen-day curricular unit aimed for middle and high school students that focused on climate change impacts on biodiversity and ecosystems. This online workbook allowed students to have a hands-on educational experience with climate change including how it may impact species. This project incorporated an interface similar to SPECIES that had a different set of questions and was used in a slightly different way. 


\section{Chapter 3: Methods}

\subsection{Approach}

The study used a quantitative component involving online active learning bounded by pre- and post-surveys. The online, active learning-based curriculum was created for the general public, exposing participants to climate change and species distribution data, highlighting potential changes in the El Paso region. Adult participants were recruited to complete the curriculum at eleven public events. A pre- and post-survey assessed to what degree this curriculum changed their awareness, perceptions and behavioral intentions towards climate change.

\subsection{Participants and site location}

This research utilized an online survey of general climate data and attitudes towards anthropogenic global climate change and was administered from the months of May to September 2017 to the public at eleven events. Pilot testing occurred during the month of April to obtain feedback on the web interface, curricula and surveys. After the pilot study was completed the curricula, surveys and website were finalized. Consenting adults 18 years and older were the target population for this study and were randomly recruited at events where people were spending leisure time around the El Paso region. Internal Review Board (IRB) approval was obtained prior to collecting any information from the participants, and all participants were required to sign a consent form indicating that they were aware that data was collected for research purposes, that their participation was voluntary, and that they could decline 
to participate at any time. In total, 97 individuals were recruited to participate in the online

survey from eleven events (Table 3.1).

\section{Table 3.1 Events where survey participants were recruited}

Event and date where survey participants were recruited. Number of surveys collected refers to participants who filled out the survey on site at the event. Post-event surveys refer to participants who were recruited at an event but filled out the survey after the event.

\begin{tabular}{|c|c|c|c|}
\hline Event Name & Date & $\begin{array}{c}\text { Number of } \\
\text { Surveys } \\
\text { Collected }\end{array}$ & $\begin{array}{l}\text { Post } \\
\text { Event } \\
\text { Surveys }\end{array}$ \\
\hline 7th Annual ESD's Earth Day Celebration & 22-Apr & 2 & 2 \\
\hline Arts and Farmers Market & 13-May & 8 & 6 \\
\hline El Paso Public Library & 15-May & 7 & \\
\hline Farmers Market at Ardovino's Desert Crossing & 10-Jun & 3 & 6 \\
\hline Sunland Park Mall & 24-Jun & 1 & \\
\hline E1 Paso Ice Cream Festival & 2-Jul & 11 & \\
\hline Fourth of July $5 \mathrm{~K}$ Run & 4-Jul & 11 & \\
\hline Alameda Auto Electric's Second Annual Car Show & 30-Jul & 7 & \\
\hline $6^{\text {th }}$ Annual Big Latch & 5-Aug & 12 & 1 \\
\hline Cadlelighters Walk for Hope & 23-Sep & 10 & \\
\hline 12th Annual Chihuahuan Desert Fiesta & 30-Sep & & 10 \\
\hline
\end{tabular}

To motivate individuals to participate in the survey an iPad raffle was advertised at each event. Each person who participated in the survey was entered in the raffle and one participant was chosen to win the iPad. After an explanation was given of what should be expected while participating in the survey the participant was logged on to a University of Texas at El Paso (UTEP) laptop from where they completed the survey. Some individuals choose to spend their time at the event rather than fill out the survey. These participants signed a consent form at the event stating that they were committing to take the survey and were handed a business card with the survey website link and password in order to take the survey at their convenience. Participants were then asked to email an acknowledgement of completion once they had completed the survey in order to be entered in the iPad raffle. Each participant had four hours to complete the survey 
once they had begun; the survey would then close after four hours from the start time despite where they were participating from.

\subsection{Survey development}

The online, active learning-based curriculum was created for the general public exposing participants to climate change, species distribution data, and water source data, highlighting potential changes in the El Paso region identified from the data. The online curriculum was completed in approximately fifteen minutes, depending on participant choices. After providing demographic information, a pre-survey was given to participants asking questions on initial thoughts on climate change and to assess to what degree this curriculum changed their awareness, perceptions and behavioral intentions towards climate change. The survey was developed on software called Qualtrics which is a web-based survey tool that can be used by anyone to create surveys, online data collection and analysis.

The curriculum was comprised of five activities and participants were initially asked to answer several questions during and after each activity. These questions would have been used to evaluate the degree to which participants learned targeted concepts from the activities in each section. The questions after each activity were removed half way through the study to shorten the survey because the length became a deterrent for participation. These questions were removed from the data analysis for participants who had answered these questions.

In the first activity, participants watched one of five videos on how carbon dioxide warming works that ranged from one to five minutes in length. The second activity asked participants to explore climate data from the past to see for themselves what historical records suggest about climate change, at both global and regional scales. The third activity consisted of a 
short video educating the participant on how climate models worked and allowed them to explore future climate data themselves, again at the global and regional scales. The next step enabled participants to explore the expected impacts of climate change on distributions of fauna in the El Paso region. The curriculum was created online, accessing climate change and species distribution data through the internet. The curriculum was based on the species that have been documented over many years in the El Paso region and consisted of lists of species and maps of their distribution in and around the Franklin Mountains. The aim was to use species the El Paso locals are familiar with and that are native to the region to peak the public's interest, as was shown in the study by Evans \& Lawrence (2014). The last activity allowed participants to view water supply information and how water sources in the El Paso region would be affected by climate change. Evaluation of changes in beliefs, perceptions, and behavioral intentions followed at the end of the interface when individuals were asked to participate in a post-survey.

Questions in the pre-survey attempted to elicit participant views that would enable categorization as dismissive, uncommitted, concerned or alarmed, following the typology of Hine et al. (2016). The pre-survey consisted of 17 questions and the post-survey consisted of 16 questions, answer choices were on a one to seven Likert scale with most of the answer choices ranging from 'Strongly Agree' to Strongly Disagree'. Examples of questions found in the presurvey have been included below in Table 3.2. 


\section{Table 3.2 Example of survey questions}

Question examples with answer choices from the pre-survey on a 7-point Likert scale. A complete list of survey questions can be found in Appendix A.

\begin{tabular}{|c|c|c|c|c|c|c|c|}
\hline $\begin{array}{c}\text { How important is } \\
\text { the issue of climate } \\
\text { change? }\end{array}$ & & $\begin{array}{l}\text { To what degree } \\
\text { are you aware } \\
\text { of potential } \\
\text { local impacts of } \\
\text { climate change } \\
\text { on biodiversity? }\end{array}$ & & $\begin{array}{l}\text { How concerned are } \\
\text { you that local } \\
\text { animal and plant } \\
\text { species may be } \\
\text { threatened to } \\
\text { become extinct? }\end{array}$ & \multicolumn{3}{|c|}{$\begin{array}{c}\text { I believe } \\
\text { climate change } \\
\text { will affect me } \\
\text { personally. }\end{array}$} \\
\hline Very important & 7 & Extremely aware & 7 & Very concerned & 7 & Strongly agree & 7 \\
\hline Important & 6 & $\begin{array}{l}\text { Moderately } \\
\text { aware }\end{array}$ & 6 & $\begin{array}{l}\text { Moderately } \\
\text { concerned }\end{array}$ & 6 & Agree & 6 \\
\hline $\begin{array}{l}\text { Moderately } \\
\text { important }\end{array}$ & 5 & Somewhat aware & 5 & $\begin{array}{l}\text { Somewhat } \\
\text { concerned }\end{array}$ & 5 & $\begin{array}{l}\text { Somewhat } \\
\text { agree }\end{array}$ & 5 \\
\hline Not sure & 4 & Unsure & 4 & Unsure & 4 & Unsure & 4 \\
\hline $\begin{array}{l}\text { Moderately } \\
\text { unimportant }\end{array}$ & 3 & $\begin{array}{l}\text { Somewhat } \\
\text { unaware }\end{array}$ & 3 & $\begin{array}{l}\text { Somewhat } \\
\text { unconcerned }\end{array}$ & 3 & $\begin{array}{l}\text { Somewhat } \\
\text { disagree }\end{array}$ & 3 \\
\hline Of little importance & 2 & $\begin{array}{l}\text { Moderately } \\
\text { unaware }\end{array}$ & 2 & $\begin{array}{l}\text { Moderately } \\
\text { unconcerned }\end{array}$ & 2 & Disagree & 2 \\
\hline Unimportant & 1 & Unaware & 1 & Unconcerned & 1 & $\begin{array}{l}\text { Strongly } \\
\text { disagree }\end{array}$ & 1 \\
\hline
\end{tabular}

The curriculum activity followed the 5 Es Instructional Model which is represented by a recursive cycle of cognitive stages that focuses on inquiry-based learning as explained in Carr et al. (2007). The 5 Es of the model are engage, explore, explain, elaborate, and evaluate. To engage, the activity created interest by raising a question and a problem and allowing participants to voice their perception and current awareness on global climate change. Part of this was facilitated by a pre-survey to obtain quantitative information. In the explore phase, participants had an opportunity to investigate global climate change further by watching several videos and visiting websites with climate data that allowed them to reach a common understanding in this concept. Participants had an opportunity to think critically about the information they were viewing and test the predictions they initially had formed within the limits of the activity. The active learning activity led participants to stimulate their curiosity which 
would lead them to discover new insights, confirm their prior assumptions or challenge their prior perceptions.

An explanation of the impacts of anthropogenic global climate change was facilitated through the climate data, Lifemapper data, and water source information they examined. At this step participants had a chance to explain their conceptual understanding and contrast what they had learned with their previous misconceptions. Participants were further able to elaborate what they had learned as they made the connection between how global warming occurs and the impacts it has on temperature, fauna, and water sources. After making these connections, participants had a chance to use previous information from the curriculum to ask questions and make decisions on the concept of climate change. Throughout the activity, participants were given the chance to draw reasonable conclusions from the evidence they were viewing.

Participants then had an opportunity to evaluate their previous misconceptions and what they had learned through the post-survey as they answered questions that voiced how their perception and awareness had changed. The investigator was also able to evaluate each participant with the post-survey to determine if initial perception and awareness on humancaused climate change had indeed changed.

\subsection{Data analysis}

After survey responses had been collected, answers were reverse coded for items that had been phrased from a "positive" to a "negative" scale to be consistent with the "negative" to "positive" form of the majority of the questions. The data were then exported from Qualtrics into a Microsoft Excel worksheet. Participants were removed from the analysis if their responses 
were missing answers in the pre-survey, post-survey or demographic section. The sample size after removal of incomplete responses was 76 survey participants.

Participant answers on the pre- and post- surveys were summed with a higher total meaning a greater degree of concern about climate change ( 1 to 7 scale, where $7=$ greater concern). Participants were then categorized into four groups, 'Alarmed', Concerned', Uncommitted', and Dismissive' using the total score of their responses for each survey as follows: Alarmed $=4$, Concerned $=3$, Uncommitted $=2$, and Dismissive $=1$. The change in level of concern pre- and post- learning activity for each participant was then identified as 'Increase', a 'Decrease' or 'No Change' in concern (Table 3.3).

Table 3.3 Change of concern level based on score difference

Participants categorized based on their score difference from the pre- and post-survey.

\begin{tabular}{|l|l|}
\hline Difference & Change \\
\hline Pre-survey $=$ Post-Survey & No Change \\
\hline Pre-survey $<$ Post-Survey & Increase in Concern Level \\
\hline Pre-survey $>$ Post-Survey & Decrease in Concern Level \\
\hline
\end{tabular}

Results were statistically analyzed using SPSS and Minitab. Pre- and post-survey results were statistically analyzed, including basic summary statistics to determine if post-activity responses differed significantly from pre-activity responses. The Likert items for the pre-survey were added up to derive a Likert scale that could later be used to run parametric tests on the data and the same was done for the post-survey. A Cronbach's alpha was run to analyze pre- and post-survey results independently. Cronbach's alpha was used because it is a measure of internal consistency of the data and a measure of scale reliability. The pre-survey questionnaire consisted of 17 items, and had Cronbach's alpha of 0.87 indicating a high level of internal consistency. The post-survey questionnaire consisted of 16 items and had a high level of internal consistency with a Cronbach's alpha of 0.80 . The mean for each of the participants' responses was calculated 
in Excel and then using Minitab a paired t-test was run on the pre-and post-survey mean score difference. A paired t-test is used to compare the means of two sample sets when the observations in one sample can be paired with observations in the other sample and therefore was used to find change in concern.

Demographic information was used to find correlations between each demographic variable and the change in degree of concern. Non-parametric tests were used to analyze the relationship between demographics and change in concern because the data were not continuous and included ordinal data. Non-parametric tests included Spearman's and Point-Biserial correlations. A Spearman Rho correlation is a non-parametric test that can be used to measure the degree of association between two variables. A Spearman's correlation was used to find if there was a statistically significant relationship between education level and change in concern. Education level was analyzed using a Spearman's correlation because this variable was considered ordinal even though change in concern was continuous. Point-Biserial correlation measures the strength of association between a continuous variable and a dichotomous variable. A Point-Biserial test was used for gender and ethnicity because they were both binary variables. Gender was measured with two choices, 'Male' and 'Female' making it a dichotomous variable. Ethnicity of participants was categorized into two groups, 'Hispanic' or 'Non-Hispanic' making the data dichotomous.

One demographic variable that did not require a non-parametric test was age group and concern change. A Pearson's correlation is used to assess the strength of association between two continuous variables and was used to assess if there was a statistically significant relationship between age group and change in concern. A Pearson's correlation test was used for these variables because both variables were continuous data. 


\section{Chapter 4: Results}

\subsection{Overall results}

Change in participants' concern level was highest for the 'No Change' category (51\%) followed by the 'Increase' (26\%) and 'Decrease' (23\%) change categories (Figure 4.1). Parametric tests used to compare pre- and post-survey results included Cronbach's alpha and a paired t-test. A normality test was run on the 'Score Difference' (change in concern) of the preand post-survey and found that the data was normally distributed (Mean $=-0.09$; Standard deviation $=0.73 ; \mathrm{P}$-value $=0.10$ ). Results show that the mean post-activity scores were lower $(5.22 \pm 0.82)$ than pre-survey scores $(5.32 \pm 0.94)$, a decrease of $0.1(95 \% \mathrm{CI},-0.27,0.07)$ in the mean level of concern after engaging in the learning activity (Figure 4.2). This difference was not statistically significant $(\mathrm{T}$-value $=-1.17, \mathrm{P}$-value $=0.24, \alpha=0.05)$. 
Figure 4.1 Percentage of change in concern level

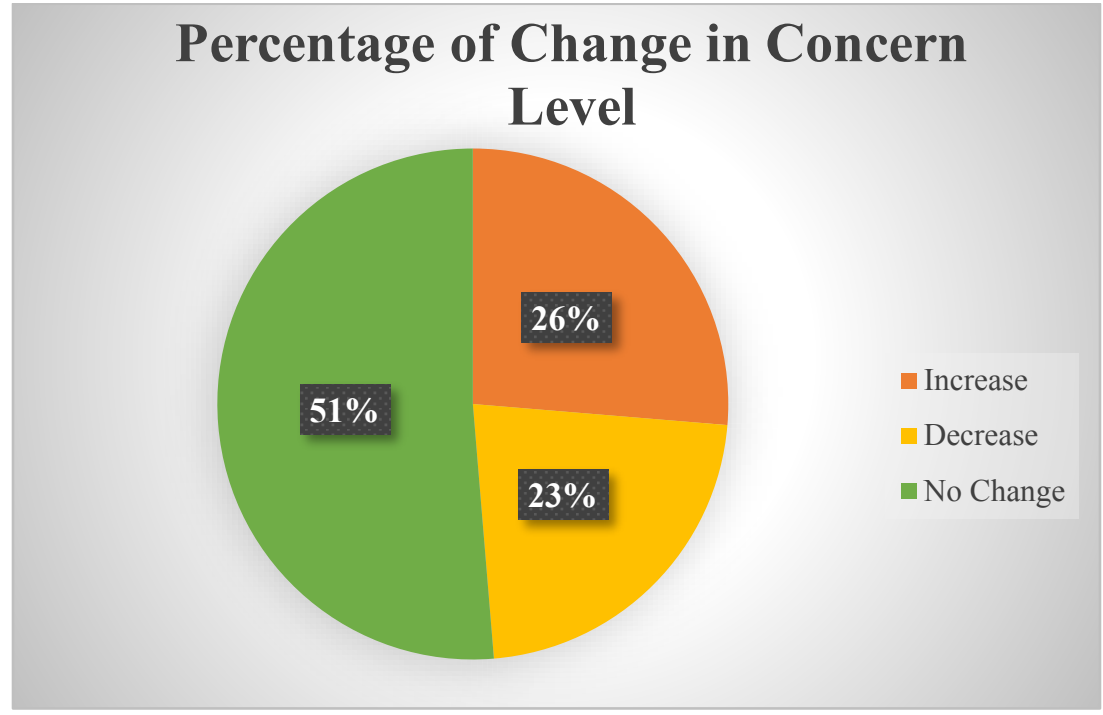

Figure 4.1 Change of concern level showing percentage of participant's who had 'No Change', 'Increase' in concern, or 'Decrease' in concern $(n=76)$.

\section{Figure 4.2 Paired t-test: Concern of climate change}

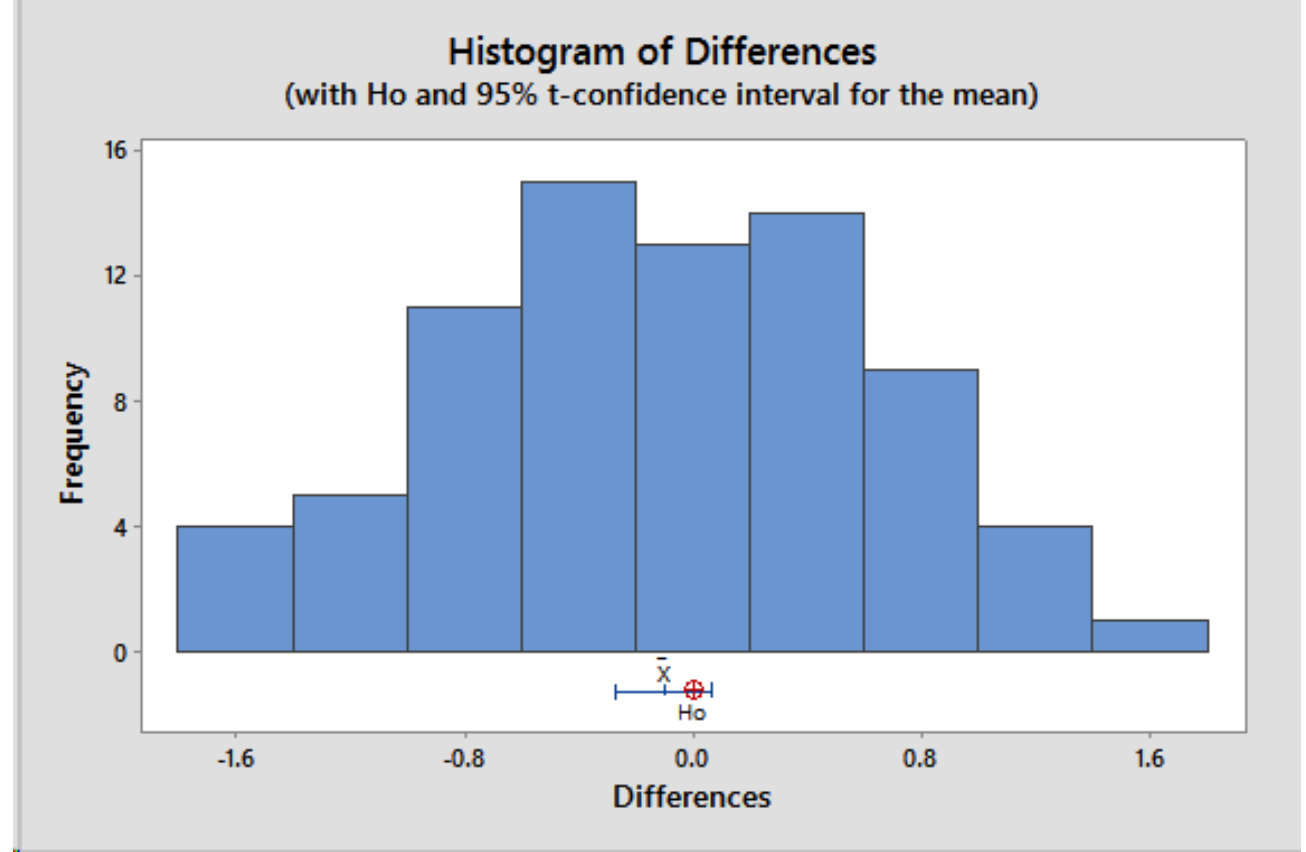

Initial concern of climate change compared to post-activity concern for each participant using a Paired ttest. 


\subsection{Non-parametric tests on demographic data}

Results were disaggregated by age, gender, race, and political view. Percentage of participants for age groups were as follows: 18-29 (44.7\%), 30-39 (19.7\%), 40-49 (15.8\%), 50$59(13.3 \%), 60-69(5.3 \%)$ and Over $70(1.3 \%)$. The majority of participants were initially concerned about climate change, with younger participants (50-59) being the most concerned initially (60.0\%) (Table 4.1). Overall, the highest level for initial concern level for participants was 'Concerned' (51.3\%). Younger adults (18-29) had a larger 'Increase' in concern (38.2\%) and adults (40-59) had predominantly 'No Change' in concern (66.7\%-70\%) (Figure 4.3).

Table 4.1 Initial climate change belief of participants by age Initial Climate Change Belief of participants disaggregated by Age. Missing Values indicate no responses were recorded for the level of concern in that age group.

\begin{tabular}{|l|r|r|r|r|r|r|}
\hline \multicolumn{7}{c|}{ Initial Climate Change Belief } \\
Age & \multicolumn{1}{c}{$18-29$} & \multicolumn{1}{c|}{$30-39$} & $40-49$ & $50-59$ & $60-69$ & \multicolumn{1}{c|}{ Over 70 } \\
\hline Alarmed & $23.5 \%$ & $40.0 \%$ & $41.7 \%$ & $20.0 \%$ & $75.0 \%$ & \\
\hline Concerned & $50.0 \%$ & $53.3 \%$ & $50.0 \%$ & $60.0 \%$ & $25.0 \%$ & $100.0 \%$ \\
\hline Uncommitted & $20.6 \%$ & $6.7 \%$ & $8.3 \%$ & $10.0 \%$ & & \\
\hline Dismissive & $5.9 \%$ & & & $10.0 \%$ & & \\
\hline
\end{tabular}

Figure 4.3 Change in concern level by age group

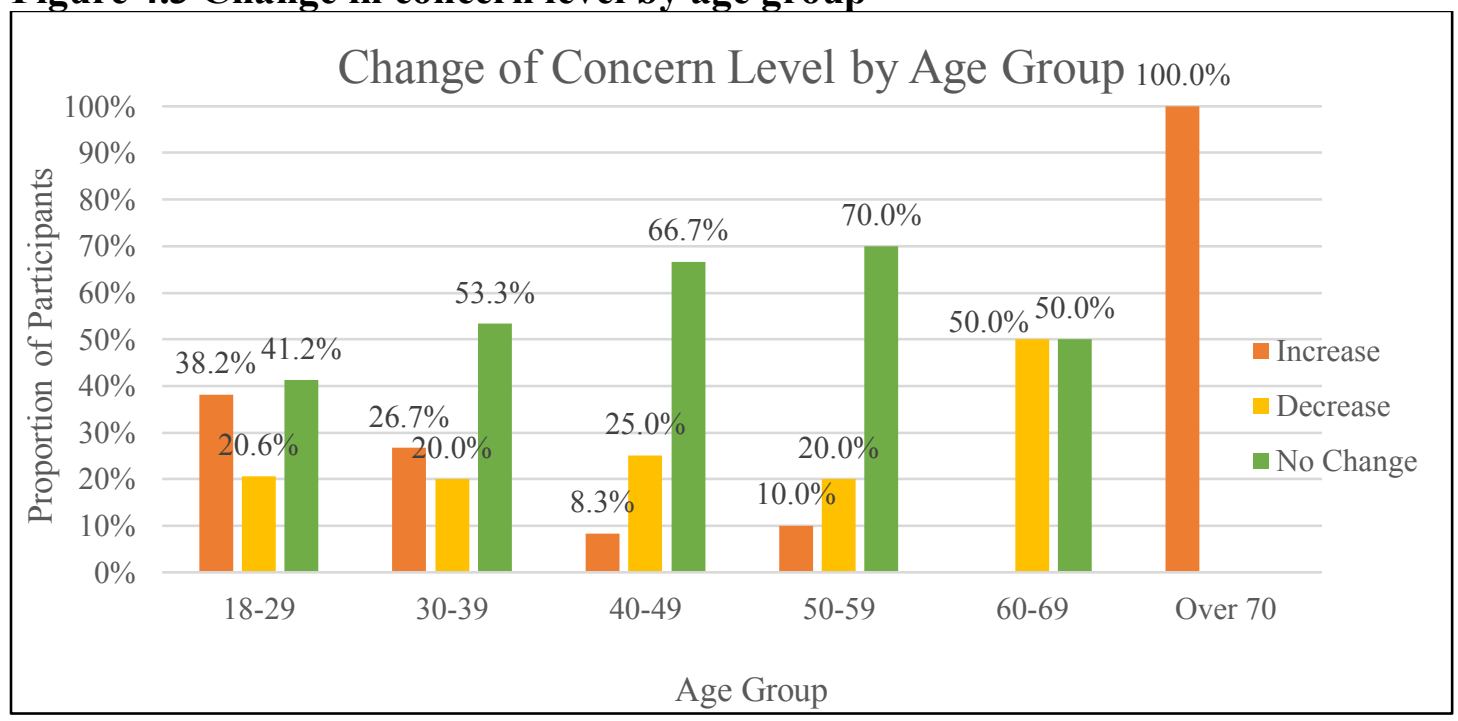

Figure 4.3 Change in concern level and participant age given in percentages. Missing concern levels indicate there were no participants in that category for that age group $(n=76)$. 
A Pearson's Correlation was used to determine whether there was a statistically significant association between age group of a participant and change in concern. There was a weak negative correlation, signifying there was a decrease in concern, between the two variables that was not statistically significant $(\mathrm{r}(74)=-0.172, \mathrm{p}=0.138)$ (Figure 4.4).

Figure 4.4 Association of change in concern and age

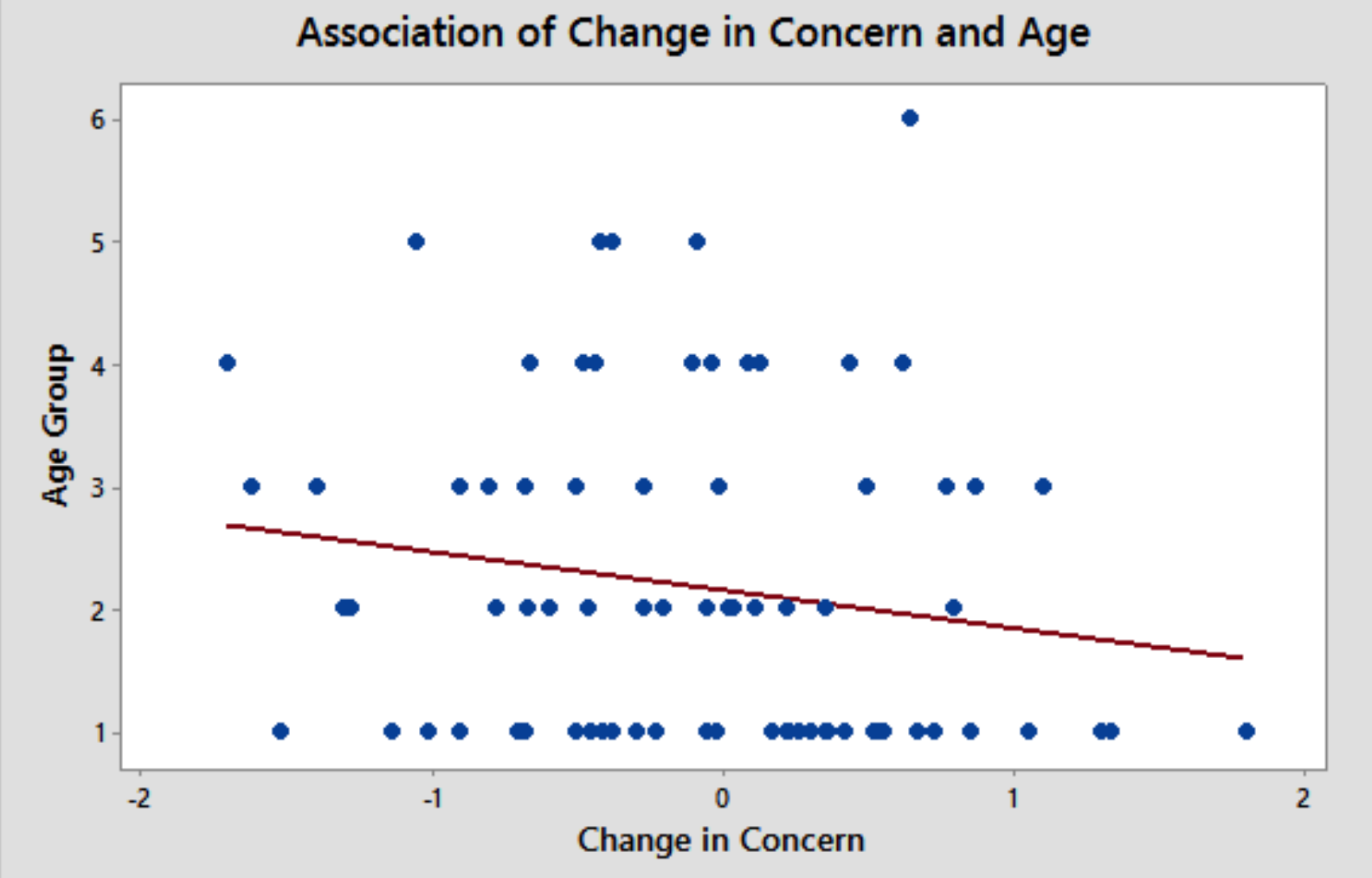

Association between age group of participants and change in concern of pre-and post-survey. Participant age was categorized into groups and recoded as follows: $1=18-29,2=30-39,3=40-49,4=50-59,5=$ $60-69,6=70$ and over.

Of the 76 respondents, $48 \%$ were male and $52 \%$ were female. Of the females, $22.3 \%$ increased in concern, $19.4 \%$ decreased in concern and $58.3 \%$ had no change in concern level for climate change. For males, 30.0\% increased in concern, $25.0 \%$ decreased in concern and $45.0 \%$ had no change in concern for climate change. Overall, men had a higher 'Increase' in concern level (30.0\%) and women had a high percentage of 'No Change' in concern level $(58.3 \%)$ (Figure 4.5). 
Figure 4.5 Change in concern level by gender

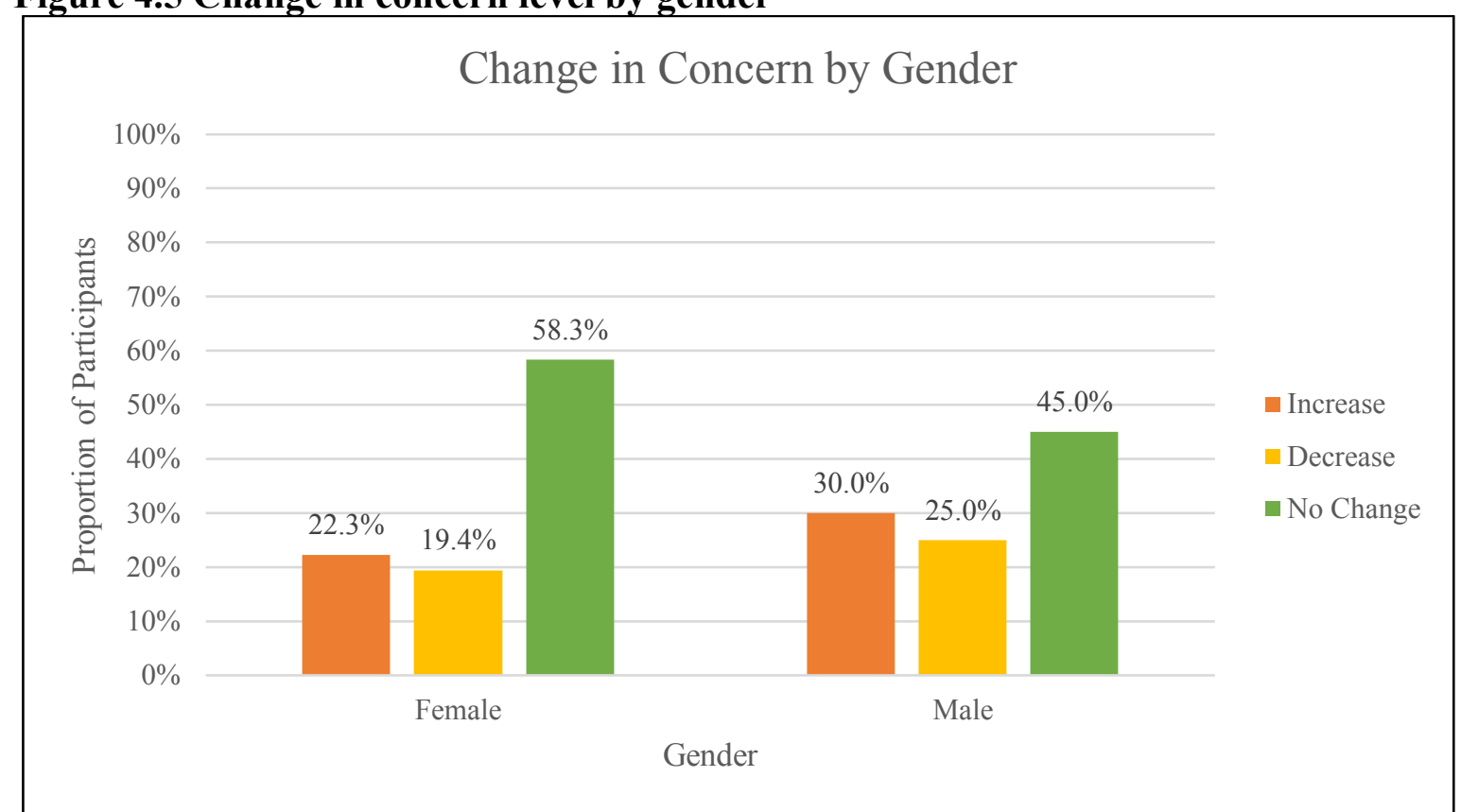

Change of concern level of participants and gender given as number of participants $(n=76)$.

Association of gender with change in concern was statistically analyzed using a PointBiserial correlation. No association was found between the participants' gender and change in concern $\left(\mathrm{r}_{\mathrm{pb}}=0.081, \mathrm{p}=0.488\right)$ which make the correlation not statistically significant, but there was a positive slope.

Ethnicity of participants were grouped into 'Hispanic' or 'Non-Hispanic' and $70 \%$ of participants were Hispanic while $30 \%$ were non-Hispanic. Of the 76 participants, six participants did not answer the question about their ethnicity $(\mathrm{n}=71)$. Of the Hispanic $26.0 \%$ had an increase in concern, $24.0 \%$ had a decrease in concern and $50.0 \%$ had no change in concern level. Non-Hispanics had an increase of $28.6 \%$ increase in concern, $14.3 \%$ decrease in concern and $57.1 \%$ no change in concern level. Hispanic participants had a higher percentage of 'Decrease' in concern level and had a lower 'Increase' in concern level (Figure 9). NonHispanics had a higher percentage of 'No Change' in concern level although there 'Increase' in concern level was higher than Hispanics. 
Figure 4.6 Change in concern level by ethnicity

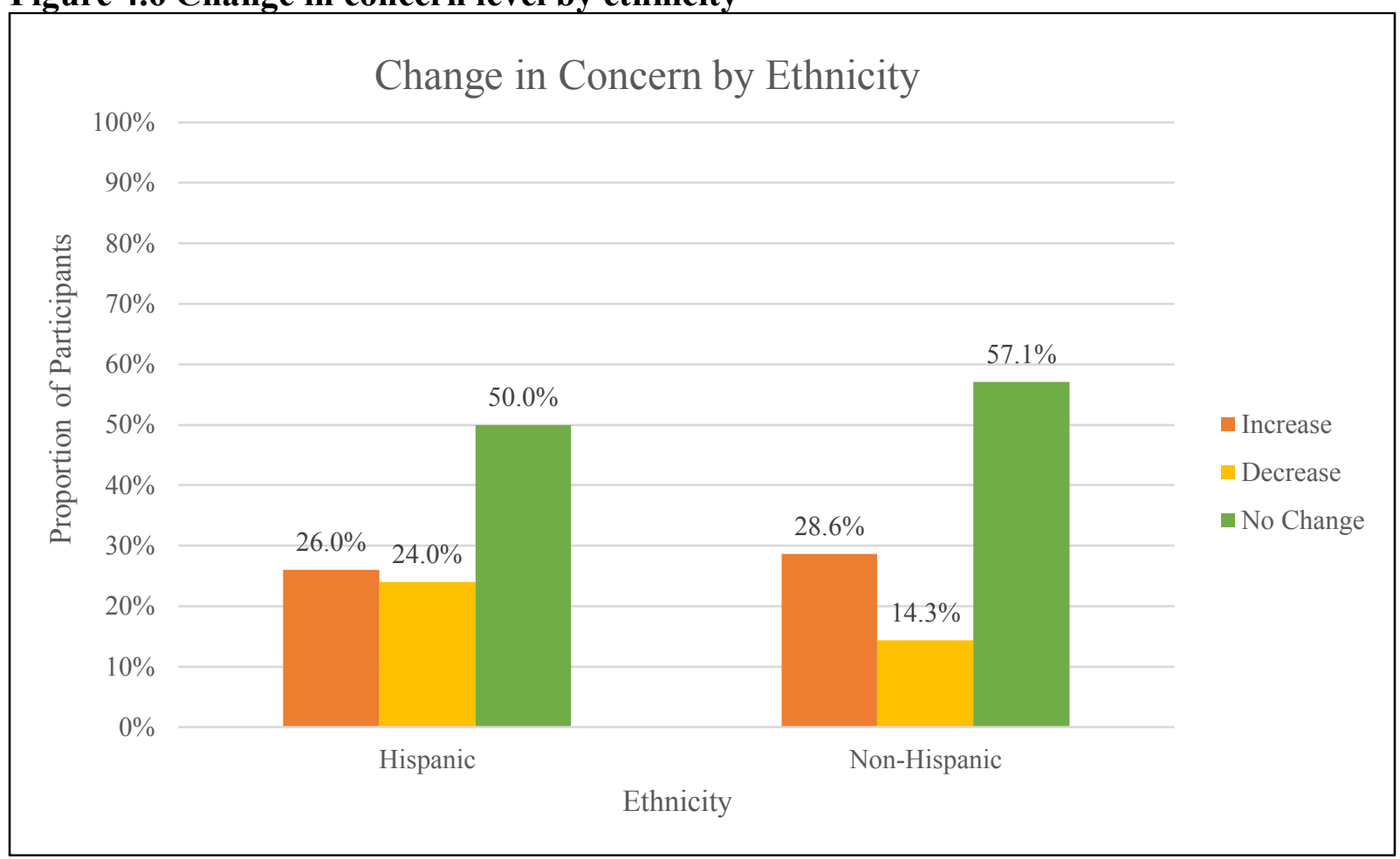

Change in concern level and education level of participants shown in percentages $(n=71)$.

A small negative association between ethnicity and change in concern was found using a Point-Biserial correlation. This correlation was not found to be statistically significant $\left(\mathrm{r}_{\mathrm{pb}}=-\right.$ $0.105, \mathrm{p}=0.388)$, with a negative slope.

When looking at gender and ethnicity, Hispanic women had a high percentage of 'No Change' in concern level $(56.5 \%-61.5 \%)$ in the post-activity. Women who were non-Hispanic had a higher percentage of an 'Increase' in concern level (23.1\%). Men who were Hispanic had a higher percentage in an 'Increase' concern level (30.8\%) compared to non-Hispanic males and women (Figure 4.7). 
Figure 4.7 Change in concern level by gender and ethnicity

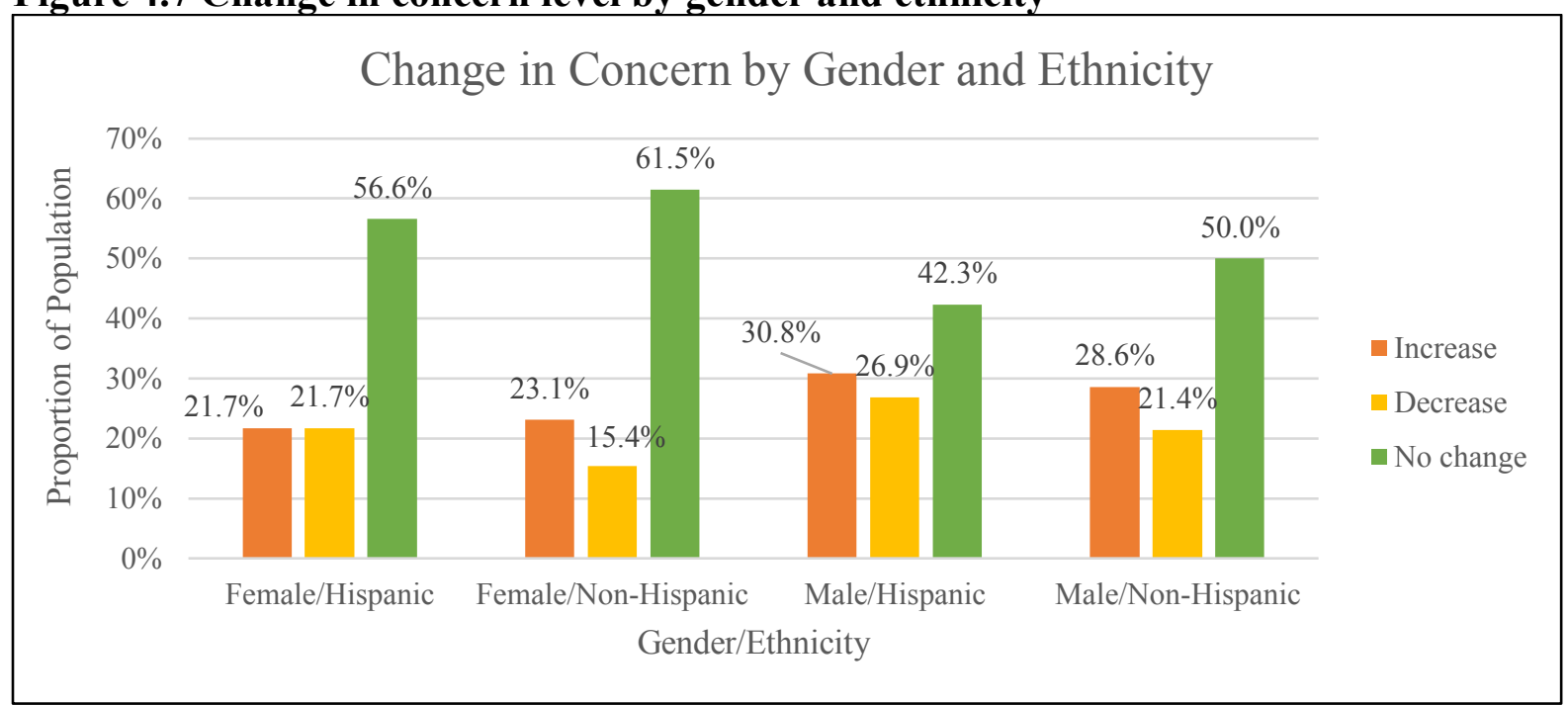

Change in concern level disaggregated by gender and ethnicity given in percentages $(n=76)$.

Political view was divided in groups as follows: Liberal (19.7\%), Moderate (28.9\%), Conservative (25.0\%), Rather not say (7.9\%), and Not sure (18.4\%). Participants who associated as conservative had the highest percentage of 'Increase' in concern level (36.8\%) than the other views. Participants who chose not to associate with a political view $(66.7 \%)$ or those who were unsure (64.3\%) had the highest percentage of 'No Change' in concern level. Participants who associated as conservative had a smaller percentage (42.1\%) of 'No Change' when compared to participants who associated as liberal (53.4\%); liberals $(13.3 \%)$ had a smaller percentage of 'Increase' in concern than conservatives (36.8\%) (Figure 4.8). 
Figure 4.8 Change in concern level by political view

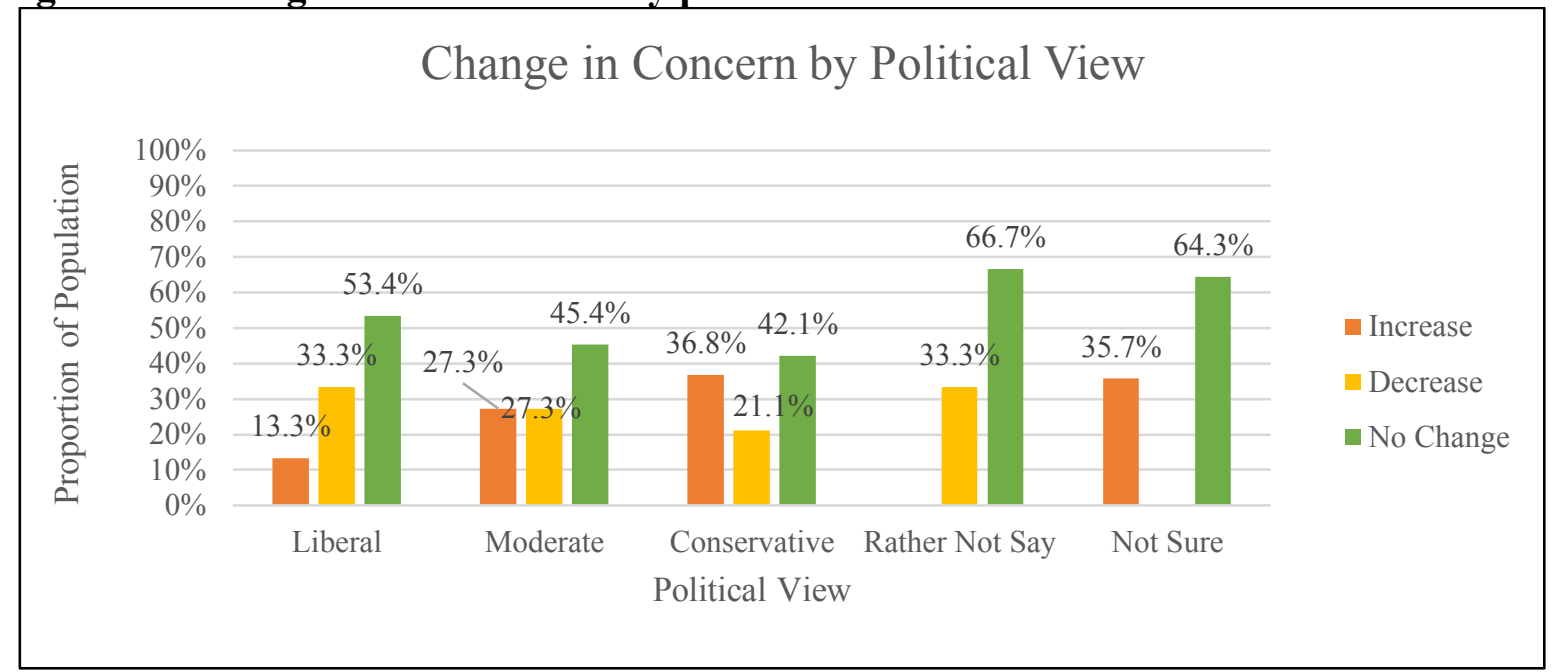

Change in concern level and political view given in percentages. Missing concern levels indicate there were no participants for that political view $(n=76)$.

Participant education level percentage were as follows: some High School or less $(2.6 \%)$, High school graduate (15.8\%), Some College (23.7\%), Bachelors (22.4\%), Some graduate (5.3\%), Masters (23.7\%), Doctorate (2.6\%), and Other (3.9\%). The percentage of participants with 'No Change' was high throughout the education levels. Participants who had any college education had the highest 'No Change' in concern level (Figure 4.9). 
Figure 4.9 Change in concern level by education level

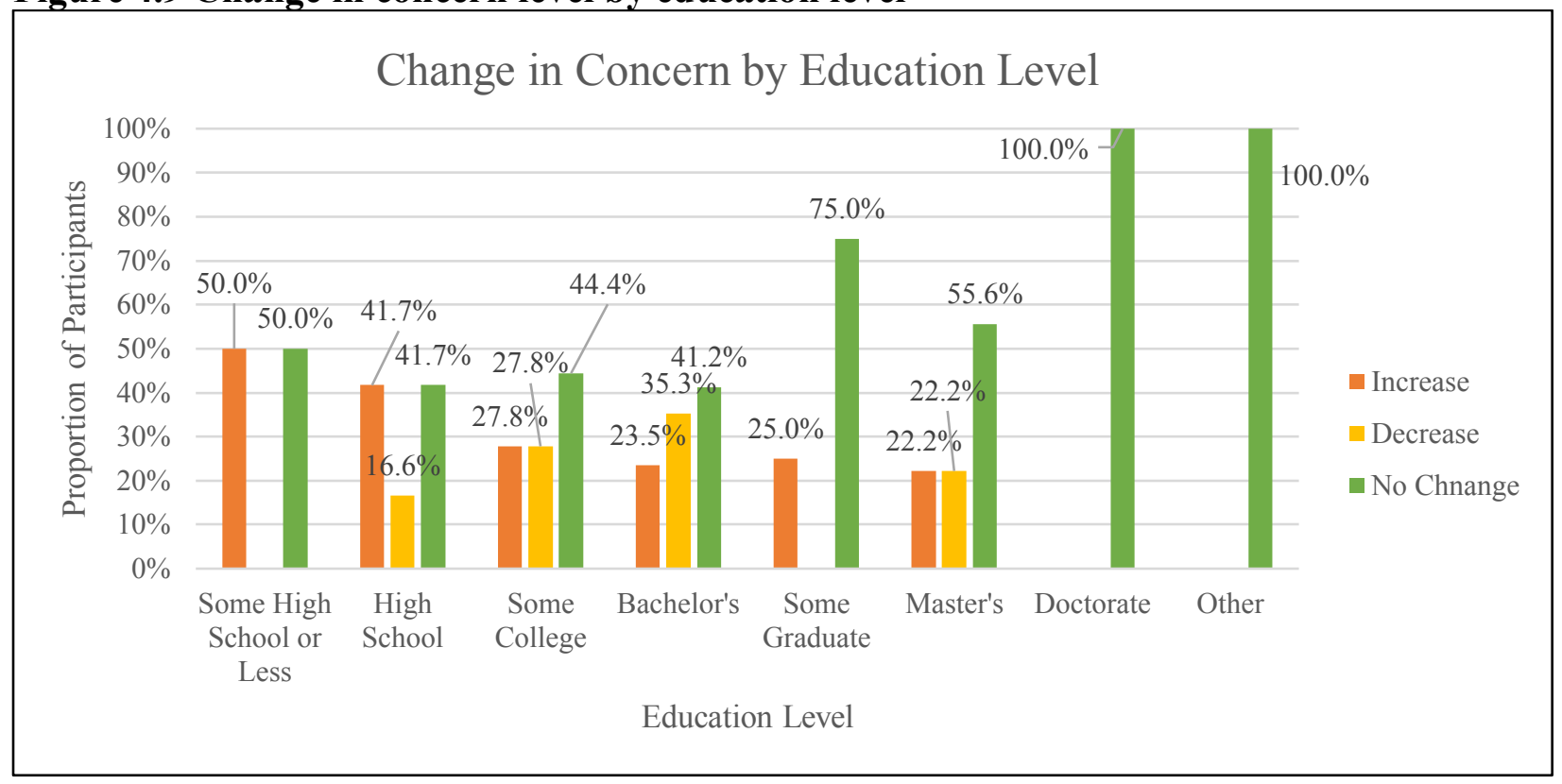

Change of concern level and education level shown in percentages. missing concern levels indicate there were no participants for that education level $(n=76)$.

The Spearman's correlation revealed a weak negative association between education level and change in level of concern (Figure 4.10), which was not statistically significant $\left(\mathrm{r}_{\mathrm{s}}=\right.$ $0.12, \mathrm{p}=0.35$, alpha $=0.05)$. 
Figure 4.10 Association of change in concern and education level

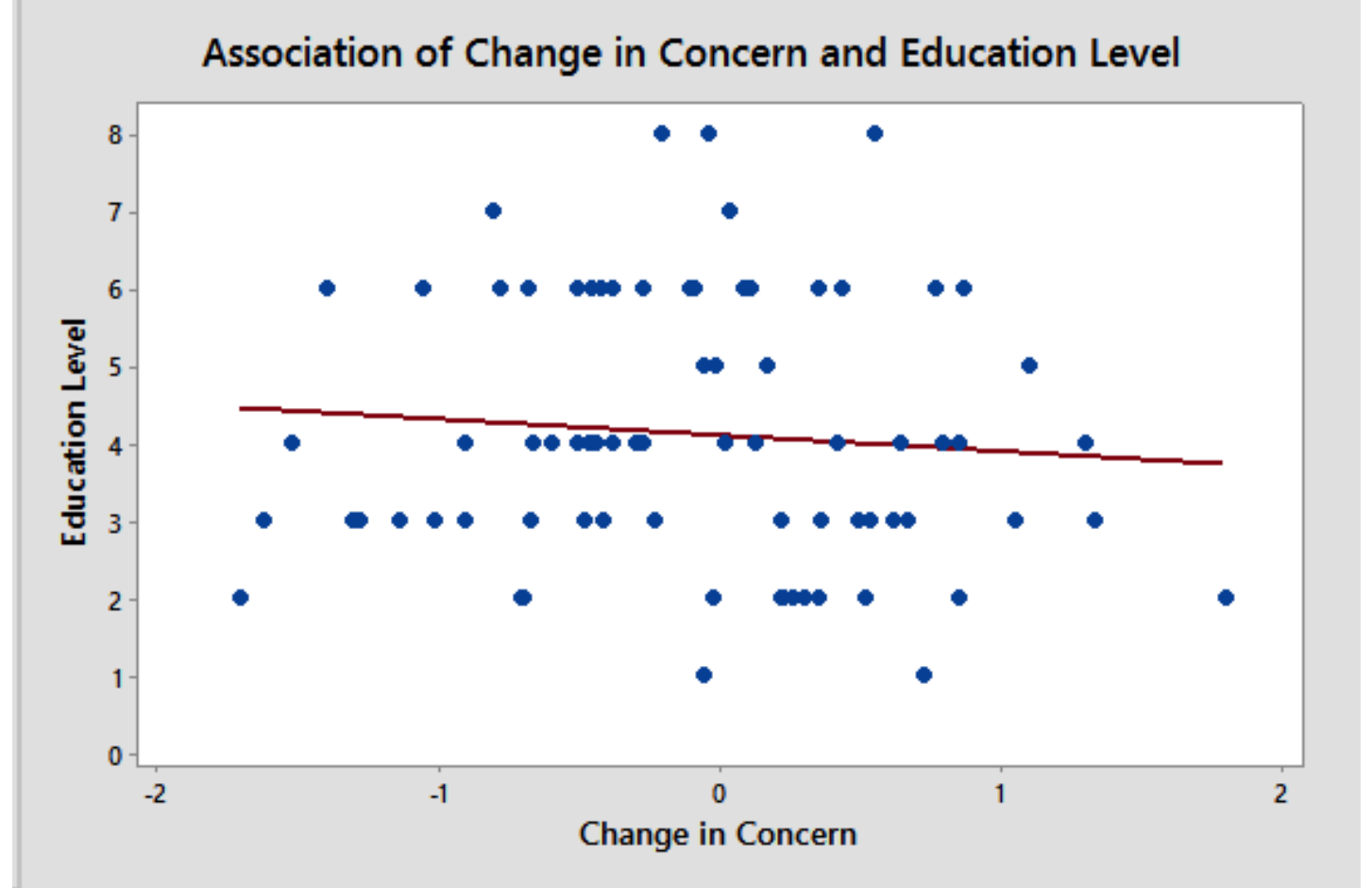

Association between Education level of participant and the score difference from the pre-survey and postsurvey. Participant responses were recoded as follows: $1=$ Some High School or Less, $2=$ High School Diploma, 3 = Some College, $4=$ Bachelors, $5=$ Some Graduate School, $6=$ Masters, $7=$ Doctorate, and 8 $=$ Other. 


\section{Chapter 5: Discussion and conclusions}

This study targeted the general public's concern on climate change (adults 18 years and older) and if this concern would change when given local climate change impacts with an active learning activity (hands-on). Data analysis compared a pre-survey given before the active learning activity to a post-survey that was given after the activity. This study sought to determine if a hands-on activity would change the concern of individuals based on the categorization of 'Alarmed', 'Concerned', Uncommitted', or 'Dismissive', hypothesizing that participants' concern who were Dismissive and Uncommitted would be more pronounced. Disaggregation of demographic data was also analyzed and correlations between gender, ethnicity, political view, and education level were made.

Political views have been the strongest predictor of environmental beliefs and a literature review completed by McCright et al. (2016) found that 67 to 69 surveys they reviewed showed that people who associated with the political left have a stronger pro-climate view than those who associate with the political right (Tjernström et al., 2008; Tranter et al., 2011; Clements et al., 2012; Engels et al., 2013; Hornsey et al., 2016). McCright et al. (2016) also found that two of the surveys that did not adhere to this consistent pattern were geographically limited samples and relatively small studies. The study found that although there was no statistically significant change in concern level for participants based on their political views, participants who associated as conservative had a higher increase in level of concern (36.8\%), becoming more alarmed, than liberals who became more alarmed (13.3\%). In contrast, more liberals had a decrease in concern (33.3\%), becoming less alarmed, than conservatives who became less alarmed (21.1\%). These results indicate that this curriculum (looking at data for themselves) was useful for increasing concern of AGW of conservatives while decreasing concern of liberals. 
This method of communicating to the public caused individuals to move away from the extremes of their political view.

Results were consistent throughout in that there was no statistically significant change in the post-activity scores when providing local climate change impacts in the form of a hands-on activity. The data analysis indicated that $51 \%$ of participants showed no change in their concern for climate change, $26 \%$ increased in their concern and $23 \%$ decreased in concern of AGW resulting in a negative score differences from the pre- to post-activity. No statistically significant correlation was found between the independent variables (gender, ethnicity, political view, and education level) and participants' mean score difference from the pre- and post-activity results. The demographic variables all had a weak correlation in concern change.

Furthermore, results from the post-survey showed that $51 \%$ of adults had initially been concerned that climate change was occurring. The high number of already concerned adults may have led to the low number of changes in concern this study found. To interpret the results further, a summary is given below.

In many other studies, findings have shown that women have stronger pro-climate views than men (Brody et al., 2008; Tjernström et al., 2008; McCright, 2010; Kvaløy et al., 2012; Leviston, 2012; McCright et al., 2016). Although this study did not find that women had a higher increase in concern level, it could be that many women in this region are already aware of climate change impacts and that is why the study found that women had the largest no change in concern level.

Many studies have concluded that younger people have more concern for the environment and therefore have a higher concern for climate change impacts (Hornsey et al., 2016; Aldy et al., 2012, McCright, Dunlap, and Pyatt, 2016, McCright et al., 2016). This study is 
consistent with these results in that younger adults (18-29) had a larger increase in concern for AGW then the other ages. Furthermore, older adults (40-59) had the highest no change in concern level for AGW.

In a recent study, Shi et al. (2016) found that there are different dimensions of knowledge and that these shape peoples' concern of climate change and therefore knowledge continuous to be an important driver of concern (Tobler et al., 2012). Through a literature review, Shi et al. (2016) found that many studies who do not find a correlation between knowledge and concern level believe concern is linked to values instead of knowledge. Yet, through the study, Shi et al (2016) concluded that the different dimensions of knowledge are not all important for public concern on climate change and helps to better understand why some studies do not find significant relationship between knowledge and public concern level. Results for the study found that knowledge of 'physical characteristics' of climate change tends to have a negative effect on a person's concern (or no significant effect) while knowledge of 'causes of climate change' leads to a higher concern (Shi et., 2016, p 759). The results for the study at hand found that there was no significant change in participants' concern and are similar to the results found by Shi et al., (2016) when comparing the kind of information about climate change that was given to participants. This study focused more on providing physical characteristics of climate change.

There is still much uncertainty among Americans as recently as of 2011. The Global Warming Six America's has divided the public into several categories that are similar to the ones used in this study (Leiserowitz et al., 2011). The study reported that $39 \%$ of Americans fall into the groups Alarmed and Concerned and a quarter of Americans fall under Dismissive and Doubtful. Leiserowitz et al. (2011, p 5) found that a third of Americans stated, "they could easily change their minds about global warming”, which included the Disengaged (73\%) and Cautious 
$(58 \%)$ segments. Based on the on this study, it is important for climate change communication to continue to sway those in the Disengaged and Cautious groups into Concerned or Alarmed level of concern. Four of the Six Americas stated, "if given the chance to talk to an expert on the issue" they would ask nine out of the 13 questions given in the study (Leiserowitz et al., 2011, p 6). It seems the American people are seeking for the information, but have not been successful in obtaining it.

In a study by Sterman (2011), they argue how communication of technical reports and information can be improved by providing different kinds of communication rather than simply providing additional information in hopes that it will automatically change people's concern. A widening gap and low scientific literacy makes climate change messaging even more challenging (Sterman, 2011). According to Sterman (2011, p 7), "people generally do not reason in accordance with the principles of scientific method" and more concerning, other studies have found that people's belief in global warming is affected by daily temperature (Egan \& Mullin, 2010; Sterman, 2011; Li et al, 2011). Sterman (2011) also suggests that scientific communication reports should be written in plain language and with minimal technical jargon to encourage better scientific literacy and inquiry skills. Furthermore, Sterman, (2011 p 15) suggests that "effective risk communication must catalyze learning at a level deep enough to change entranched mental models" and that "mere transition of information is not sufficient" (Weber \& Stern, 2011).

\subsection{Implications}

Although Shi et al. (2016) states that studies who find no significant relationship among knowledge and public concern tend to tie values to concern of the public, further investigation needs to be done if a hands-on activity would have a greater impact on public concern of climate 
change when it includes the public's values and worldview (Kellstedt et al., 2008; Kahun et al., 2012). Measuring the results in a better way also leads to better understanding of what really impacts the public's concern on AGW. Shi et al. (2016) suggests that using an objective measure is more qualified than using a subjective measure and that public education is not a lost cause. Focusing on carefully developed messages and material while accounting for the public's values, may lead to a greater success in changing the public's concern on climate change (Shi et al., 2016) and for this study may be beneficial to try some of these suggestions along with the online curriculum.

\subsection{Suggestions for future research}

This research was preliminary and exploratory in nature, and as such, explored a wide range of potentially mediating factors using a variety of statistical tests. Future work will include engaging a statistician to assist with analyzing the data on the impact of political view on change in level of concern. This will facilitate design of more nuanced approaches to assessing potential significance of the existing results, and better framing subsequent data collection and analysis.

An issue that arose with the survey curriculum were two items that did not load properly during the distribution of the survey. In several events, it was found that the species distribution model, Lifemapper, and the climate data websites did not display the climate information due to loading issues. Online based surveys can provide a great mode to distributing online information, but can have several issues as well. The online glitches would have been remedied with proper Wi-Fi connection and distribution of the survey would have reached a larger number of participants if it had been sent out digitally with a consensus form embedded to the survey web link. For an online survey the best method of distribution is through email and other online 
sources. To target a larger audience a consent form can be included in the interface prior to sending out the survey. This would allow for participants to take the survey at their own convenience allowing participants to complete the survey and would also help with longer survey time. The questions that had initially been asked after each section $\left(\mathrm{CO}_{2}\right.$ mechanism, climate data, climate models, Lifemapper, and water source) would have been useful to evaluate the degree to which participants learned targeted concepts from the activities in each section and allowing this study to better understand the changes that occurred and if results were indeed due to a high initial concern of climate change.

Although this study was conducted in an informal setting future work may include the transferring of this active learning activity into a formal setting and creating a lengthier curriculum. One way that this can be done is through the enhancing of each activity so that each section can be a lesson given to students in the span of a week or longer. Each lesson can focus on one of the five sections in more detail and with added hands-on activities. One unit with five modules for each activity can be created for this curriculum and several hands-on activities can then be incorporated into each of the modules. Activities can vary depending on the information the teacher wishes to cover and can include websites, graphic organizers, concept maps, worksheets, group research projects, tests and quizzes, role playing and writing in class such as keeping journals (Bonewall \& Eison, 1991; Bellanca, 2009).

The previous activities are instructional tactics that engage a student's mind which enables them to transform from a passive learning state to an "active state where they are generators of knowledge" (Bellanca, 2009, p 7). Another important tactic for incorporating an active learning approach into the classroom includes discussion between students which can be facilitated by the teacher by pausing ten to twenty minutes during a lecture (Bonewell \& Eison, 
1991). The pauses during the lecture allow students to discuss and rework their notes with their peers leading to a better comprehension of the subject (Bonewell \& Eison, 1991). The curriculum can be used in college courses as well as for high school and middle schools. Although the curriculum seems to be advanced for younger students, Bruner (1966), a known constructivist author stated that "any subject can be taught effectively in some intellectually honest form to any child at any stage of development" (p 33).

It is important to try and convince the public of human caused climate change and the impacts it will have if no action is taken. It may be more important to begin educating the younger generations in this concept as they are the future of the world. 


\section{References}

Abdel-Monem, T., PytlikZillig, L. M., Bernadt, T. K., \& Wall, N. A. (2014). Climate Change Survey Measures: Exploring Perceived Bias and Question Interpretation. Great Plains Research, 24(2), $153-168$.

Aulls, M. W., \& Shore, B. M. (2008). Inquiry in education: the conceptual foundations for research as a curricular imperative. Taylor and Francis.

Bauer, M. W., Allum, N., \& Miller, S. (2007). What can we learn from 25 years of PUS survey research? Liberating and expanding the agenda. Public Understanding of Science, 16(1), 79-95. https://doi.org/10.1177/0963662506071287

Bedford, D. (2010). Agnotology as a Teaching Tool: Learning Climate Science by Studying Misinformation. Journal of Geography, 109(4), 159-165. https://doi.org/10.1080/00221341.2010.498121

Bedford, D., \& Cook, J. (2013). Agnotology, Scientific Consensus, and the Teaching and Learning of Climate Change: A Response to Legates, Soon and Briggs. Science \& Education, 22(8), 20192030. https://doi.org/10.1007/s11191-013-9608-3

Bedford, D. (2016). Does Climate Literacy Matter? A Case Study of U.S. Students' Level of Concern about Anthropogenic Global Warming. Journal of Geography, 115(5), 187-197. https://doi.org/10.1080/00221341.2015.1105851

Bellanca, J., (2009). 200+ Active learning strategies and projects for engaging students' multiple intelligences. Corwin Press a SAGE company.

Bolsen, T., Leeper, T. J., \& Shapiro, M. A. (2014). Doing what others do norms, science, and collective action on global warming. American Politics Research, 42(1), 65-89.

Bonwell, C. C., \& Eison, J. A. (1991). Active learning: creating excitement in the classroom. Washington, DC: School of Education and Human Development, George Washington University.

Bord, R. J., O’Connor, R. E., \& Fisher, A. (2000). In what sense does the public need to understand global climate change? Public Understanding of Science, 9(3), 205-218. 
Brulle, R. J., Carmichael, J., \& Jenkins, J. C. (2012). Shifting public opinion on climate change: an empirical assessment of factors influencing concern over climate change in the U.S., 2002-2010. Climatic Change, 114(2), 169-188. https://doi.org/10.1007/s10584-012-0403-y

Bruner, J. S. (1966). The process of education. Harvard University Press, Cambridge.

Carr, J., Sexton, U., \& Lagunoff, R. (2007). Making science accessible to English learners: A guidebook for teachers. San Francisco, CA: WestEd.

Clements, B. (2012). The sociological and attitudinal bases of environmentally-related beliefs and behavior in Britain. Environmental Politics, 21(6), 901-921. https://doi.org/10.1080/09644016.2012.724215

Climate Science Special Report Executive Summary document 2017 CSSR2017_PRINT_Executive_Summary.pdf. (n.d.). Retrieved from https://science2017.globalchange.gov/downloads/CSSR2017_PRINT_Executive_Summary.pdf

Cook, J., Nuccitelli, D., Green, S. A., Richardson, M., Winkler, B., Painting, R., ... Skuce, A. (2013). Quantifying the consensus on anthropogenic global warming in the scientific literature. Environmental Research Letters, 8(2), 024024. https://doi.org/10.1088/1748-9326/8/2/024024

Cook, J., Bedford, D., \& Mandia, S. (2014). Raising Climate Literacy Through Addressing Misinformation: Case Studies in Agnotology-Based Learning. Journal of Geoscience Education; Bellingham, 62(3), 296-306.

Cook, J., \& Jacobs, P. (2014). Scientists are from Mars, laypeople are from Venus: an evidence-based rationale for communicating the consensus on climate. Reports of the National Center for Science Education, 34(6).

Cook, J., Oreskes, N., Doran, P. T., Anderegg, W. R. L., Verheggen, B., Maibach, E. W., ... Rice, K. (2016). Consensus on consensus: a synthesis of consensus estimates on human-caused global warming. Environmental Research Letters, 11(4), 048002. https://doi.org/10.1088/1748$9326 / 11 / 4 / 048002$

Corner, A., \& Randall, A. (2011). Selling climate change? The limitations of social marketing as a 
strategy for climate change public engagement. Global Environmental Change, 21(3), 10051014. https://doi.org/10.1016/j.gloenvcha.2011.05.002

Cox, D. (2014, November 24). Are Transnational Ties Leading Latinos to Express Greater Concern about Climate Change? Retrieved November 7, 2017, from https://www.prri.org/spotlight/aretransnational-ties-leading-latinos-to-express-greater-concern-about-climate-change/

Deaton, J. (2016, September 21). There's one group of Americans that consistently cares about climate change - ThinkProgress. Retrieved November 7, 2017. https://thinkprogress.org/onegroup-that-cares-about-climate-51a94a016731/

Dunlap, R. E., Xiao, C., McCright, A. M., (2001). Politics and environment in America: Partisan and Ideological Cleavages in Public Support for Environmentalism. Environmental Politics. 10 (4), $23-48$.

Egan, P. J., \& Mullin, M. (2017). Climate Change: US Public Opinion. Annual Review of Political Science, 20(1), 209-227. https://doi.org/10.1146/annurev-polisci-051215-022857

Engels, A., Hüther, O., Schäfer, M., \& Held, H. (2013). Public climate-change skepticism, energy preferences and political participation. Global Environmental Change, 23(5), 1018-1027. https://doi.org/10.1016/j.gloenvcha.2013.05.008

Enten, H. (2014, September 24). The Racial Gap On Global Warming | FiveThirtyEight. Retrieved November 7, 2017, from https:/fivethirtyeight.com/features/the-racial-gap-on-global-warming/ Evans, L., Milfont, T. L., \& Lawrence, J. (2014). Considering local adaptation increases willingness to mitigate. Global Environmental Change, 25(Supplement C), 69-75. https://doi.org/10.1016/j.gloenvcha.2013.12.013

Framework agreement on climate change: a scientific and policy history - BF01092424.pdf. (n.d.). Retrieved from https://link.springer.com/content/pdf/10.1007/BF01092424.pdf

Funk, C., \& Kennedy, B. (2016, October 4). The Politics of Climate. Retrieved November 7, 2017, from http://www.pewinternet.org/2016/10/04/the-politics-of-climate/

GISTEMP Team, (2016) GISS Surface Temperature Analysis (GISTEMP). NASA Goddard Institute for 
Space Studies. Dataset accessed 2016-03-15 at http://data.giss.nasa.gov/gistemp/

GISTEMP Team, 2017: GISS Surface Temperature Analysis (GISTEMP). NASA Goddard Institute for Space Studies. Dataset accessed 2017-10-24 at https://data.giss.nasa.gov/gistemp/.

Hake, R., (1998) Interactive-Engagement vs. Traditional Methods: A Six-Thousand-Student Survey of Mechanics Test Data for Introductory Physics Courses, American Journal of Physics, 66, (1), 64

Hamilton, L. C. (2011). Education, politics and opinions about climate change evidence for interaction effects. Climatic Change, 104(2), 231-242. https://doi.org/10.1007/s10584-010-9957-8

Hansen, J., Ruedy, R., Sato, M., \& Lo, K. (2010). Global Surface Temperature Change. Reviews of Geophysics, 48(4), RG4004. https://doi.org/10.1029/2010RG000345

Hecht, A. D., \& Tirpak, D. (1995). Framework agreement on climate change: A scientific and policy history. Climatic Change, 29, 371-402. doi:10.1007/BF01092424

Hijmans, R.J., Elith, J. (2016). Species distribution modelling with R. Hijmans, R.J. (2012). Crossvalidation of species distribution models: removing spatial sorting bias and calibration with a null model. Ecology 93, 679-688.

Hine, D. W., Phillips, W. J., Cooksey, R., Reser, J. P., Nunn, P., Marks, A. D. G., .. Watt, S. E. (2016). Preaching to different choirs: How to motivate dismissive, uncommitted, and alarmed audiences to adapt to climate change? Global Environmental Change, 36, 1-11. https://doi.org/10.1016/j.gloenvcha.2015.11.002

Hobson, K., \& Niemeyer, S. (2011). Public responses to climate change: The role of deliberation in building capacity for adaptive action. Global Environmental Change, 21(3), 957-971. https://doi.org/10.1016/j.gloenvcha.2011.05.001

Hollander, M., Wolfe, D. A., \& Chicken, E. (2013). Nonparametric statistical methods. John Wiley \& Sons.

Hornsey, M. J., Harris, E. A., Bain, P. G., \& Fielding, K. S. (2016). Meta-analyses of the determinants and outcomes of belief in climate change. Nature Climate Change, 6(6), 622-626. 
https://doi.org/10.1038/nclimate2943

Hsiang, S., Kopp, R., Jina, A., Rising, J., Delgado, M., Mohan, S., ... Oppenheimer, M. (2017).

Estimating economic damage from climate change in the United States. Science, 356(6345), $1362-1369$.

Interagency Working Groups. (n.d.). Retrieved November 17, 2017, from

http://www.globalchange.gov/about/iwgs

IPCC, (2007b) Climate Change 2007: The Physical Science Basis. Contribution of Working Group I to the Fourth Assessment Report of the Intergovernmental Panel on Climate Change, ed. S. Solomon, D. Qin, M. Manning, Z. Chen, M. Marquis, K. B. Averyt, M. Tignor, and H. L. Miller. United Kingdom and New York: Cambridge University Press.

IPCC, 2013: Summary for Policymakers. In: Climate Change 2013: The Physical Science Basis.

Contribution of Working Group I to the Fifth Assessment Report of the Intergovernmental Panel on

Climate Change [Stocker, T.F., D. Qin, G.-K. Plattner, M. Tignor, S. K. Allen, J. Boschung, A.

Nauels, Y. Xia, V. Bex and P.M. Midgley (eds.)]. Cambridge University Press, Cambridge, United Kingdom and New York, NY, USA.

IPCC, (2014) Climate Change 2014: Synthesis Report. Contribution of Working Groups I, II and III to the Fifth Assessment Report of the Intergovernmental Panel on Climate Change [Core Writing Team, R.K. Pachauri and L.A. Meyer (eds.)]. IPCC, Geneva, Switzerland, 151 pp.

Kahan, D. M., Peters, E., Wittlin, M., Slovic, P., Ouellette, L. L., Braman, D., \& Mandel, G. (2012). The polarizing impact of science literacy and numeracy on perceived climate change risks. Nature Climate Change, 2(10), 732-735.

Kellstedt, P. M., Zahran, S., \& Vedlitz, A. (2008). Personal Efficacy, the Information Environment, and Attitudes Toward Global Warming and Climate Change in the United States. Risk Analysis, 28(1), 113-126. https://doi.org/10.1111/j.1539-6924.2008.01010.x 
Kowalski, P., \& Taylor, A. K. (2009). The Effect of Refuting Misconceptions in the Introductory Psychology Class. Teaching of Psychology, 36(3), 153-159. https://doi.org/10.1080/00986280902959986

Kohut A, Keeter S, Doherty C, Dimock M. (2009). Scientific achievements less prominent than a decade ago: Public praises science; scientists fault public, media. Pew Research Center for People \& the Press. http://www.people-press.org/files/legacy-pdf/528.pdf.

Laws, P., D. Sokoloff, and R. Thornton, Promoting Active Learning Using the Results of Physics Education Research. UniServeScience News, (Vol. 13), 14-19.

Leiserowitz, A., Maibach, E. W., Roser-Renouf, C., Feinberg, G., \& Howe, P. (2013). Climate change in the American mind: Americans' global warming beliefs and attitudes in April 2013.

Leiserowitz, A., E. Maibach, C. Roser-Renouf, G. Feinberg, S. Rosenthal, and J. Marlon (2014), Climate Change in the American Mind: Americans' Global Warming Beliefs and Attitudes in November 2013. Yale University and George Mason University. Yale Project on Climate Change Communication, New Haven, Conn.

Levine, A. S., \& Kline, R. (2017). A new approach for evaluating climate change communication. Climatic Change, 142(1-2), 301-309. https://doi.org/10.1007/s10584-017-1952-x

Lewandowsky, S., Gignac, G. E., \& Vaughan, S. (2012). The pivotal role of perceived scientific consensus in acceptance of science. Nature Climate Change, 3(4), 399-404. https://doi.org/10.1038/nclimate1720

Lewandowsky, S., Gignac, G., \& Vaughan, S. (2013). The pivotal role of perceived scientific consensus in acceptance of science (Vol. 3). https://doi.org/10.1038/nclimate1720

Li, Y., Johnson, E. J., \& Zaval, L. (2011). Local Warming: Daily Temperature Change Influences Belief in Global Warming. Psychological Science, 22(4), 454-459.

Lifemapper Project. Informatics Biodiversity Research Center, University of Kansas. http://lifemapper.org/

Loyens, S. M. M., \& Gijbels, D. (2008). Understanding the effects of constructivist learning 
environments: introducing a multi-directional approach. Instructional Science, 36(5-6), 351-357. https://doi.org/10.1007/s11251-008-9059-4

Marquart-Pyatt, S. T., Shwom, R. L., Dietz, T., Dunlap, R. E., Kaplowitz, S. A., McCright, A. M., \& Zahran, S. (2011). Understanding Public Opinion on Climate Change: A Call for Research. Environment: Science and Policy for Sustainable Development, 53(4), 38-42. https://doi.org/10.1080/00139157.2011.588555

McCarthy, J. J., \& Intergovernmental Panel on Climate Change (Eds.). (2001). Climate change 2001: impacts, adaptation, and vulnerability: contribution of Working Group II to the third assessment report of the Intergovernmental Panel on Climate Change. Cambridge, UK; New York: Cambridge University Press.

McCright, A. M., \& Dunlap, R. E. (2011a). Cool dudes: The denial of climate change among conservative white males in the United States. Global Environmental Change, 21(4), 1163-1172. https://doi.org/10.1016/j.gloenvcha.2011.06.003

McCright, A. M., \& Dunlap, R. E. (2011b). The Politicization of Climate Change and Polarization in the American Public's Views of Global Warming, 2001-2010. The Sociological Quarterly, 52(2), 155-194. https://doi.org/10.1111/j.1533-8525.2011.01198.x

McCright, A. M., Marquart-Pyatt, S. T., Shwom, R. L., Brechin, S. R., \& Allen, S. (2016). Ideology, capitalism, and climate: Explaining public views about climate change in the United States. Energy Research \& Social Science, 21(Supplement C), 180-189. https://doi.org/10.1016/j.erss.2016.08.003

Montañez, M. F., Amanda, \& Montañez, M. F., Amanda. (n.d.). Conservative Republicans Really Distrust Climate Scientists [Graphic]. Retrieved November 7, 2017, from https://www.scientificamerican.com/article/conservative-republicans-really-distrust-climatescientists-graphic/

Mooney, C., \& Craighill, P. (2014, December 1). Why do black and Latino Americans support climate action so much more than whites? - The Washington Post. Retrieved November 7, 2017, from 
https://www.washingtonpost.com/news/wonk/wp/2014/12/01/why-do-black-and-latinoamericans-support-climate-action-so-much-more-than-whites/?utm_term=.3693420ef6a5

Muller, D. a., Bewes, J., Sharma, M. d., \& Reimann, P. (2008). Saying the wrong thing: improving learning with multimedia by including misconceptions. Journal of Computer Assisted Learning, 24(2), 144-155. https://doi.org/10.1111/j.1365-2729.2007.00248.x

National Research Council. (1999). Making climate forecasts matter (P. C. Stern \& W. E. Easterling, Eds.). Washington, DC: National Academy Press.

Oreskes, N. (2004). The Scientific Consensus on Climate Change. Science, 306(5702), 1686-1686. https://doi.org/10.1126/science.1103618

Oreskes, N. (2004). Beyond the Ivory Tower: The Scientific Consensus on Climate Change. Science, 306(5702), 1686-1686. https://doi.org/10.1126/science.1103618

Pachauri, R. K., Mayer, L., \& Intergovernmental Panel on Climate Change (Eds.). (2015). Climate change 2014: synthesis report. Geneva, Switzerland: Intergovernmental Panel on Climate Change.

Pidgeon, N., \& Fischhoff, B. (2011). The Role of Social and Decision Sciences in Communicating Uncertain Climate Risks (Vol. 1). https://doi.org/10.1038/nclimate1080

Plumer, B., \& Popovich, N. (2017, June 29). As Climate Changes, Southern States Will Suffer More Than Others - The New York Times. Retrieved November 6, 2017, from https://www.nytimes.com/interactive/2017/06/29/climate/southern-states-worse-climateeffects.html

Poortinga, W., Spence, A., Whitmarsh, L., Capstick, S., \& Pidgeon, N. F. (2011). Uncertain climate: An investigation into public skepticism about anthropogenic climate change. Global Environmental Change, 21(3), 1015-1024. https://doi.org/10.1016/j.gloenvcha.2011.03.001

Prince, M. (2004). Does active learning work? A review of the research. Journal of Engineering Education, 93(3), 223-231.

Proctor, R. N. (2008). Agnotology: A missing term to describe the cultural production of ignorance (and 
its study). In R. N. Proctor \& L. Schiebinger (Eds.), Agnotology: The making and unmaking of ignorance, 1-33. Stanford, CA: Stanford University Press.

Pyhälä, A., Fernández-Llamazares, Á., Lehvävirta, H., Byg, A., Ruiz-Mallén, I., Salpeteur, M., \& Thornton, T. F. (2016). Global environmental change: local perceptions, understandings, and explanations. Ecology and Society : A Journal of Integrative Science for Resilience and Sustainability, 21(3). https://doi.org/10.5751/ES-08482-210325

Redish, E. F., Saul, J. M., \& Steinberg, R. N. (1997). On the effectiveness of active-engagement microcomputer-based laboratories. American Journal of Physics, 65(1), 45-54. https://doi.org/10.1119/1.18498

Reynolds, T. W., Bostrom, A., Read, D., \& Morgan, M. G. (2010). Now What Do People Know About Global Climate Change? Survey Studies of Educated Laypeople. Risk Analysis, 30(10), 15201538. https://doi.org/10.1111/j.1539-6924.2010.01448.x

Schuldt, J. P., \& Pearson, A. R. (2016). The role of race and ethnicity in climate change polarization: evidence from a U.S. national survey experiment. Climatic Change, 136(3-4), 495-505. https://doi.org/10.1007/s10584-016-1631-3

Shi, J., Visschers, V. H. M., \& Siegrist, M. (2015). Public Perception of Climate Change: The Importance of Knowledge and Cultural Worldviews: The Importance of Knowledge and Cultural Worldviews in Climate Change Perception. Risk Analysis, 35(12), 2183-2201. https://doi.org/10.1111/risa.12406

Shi, J., Visschers, V. H. M., Siegrist, M., \& Arvai, J. (2016). Knowledge as a driver of public perceptions about climate change reassessed. Nature Climate Change, 6(8), 759-762. https://doi.org/10.1038/nclimate2997

Spence, A., Poortinga, W., \& Pidgeon, N. (2012). The Psychological Distance of Climate Change: Psychological Distance of Climate Change. Risk Analysis, 32(6), 957-972. https://doi.org/10.1111/j.1539-6924.2011.01695.x

Sterman, J. D. (2011). Communicating climate change risks in a skeptical world. Climatic Change, 
108(4), 811.

Stocker, T. (Ed.). (2014). Climate change 2013: the physical science basis: Working Group I contribution to the Fifth assessment report of the Intergovernmental Panel on Climate Change. New York: Cambridge University Press.

Study about Climate change - ClimateChangeperceptionsurvey.pdf. (n.d.). Retrieved from https://asiafoundation.org/resources/pdfs/ClimateChangeperceptionsurvey.pdf

Tippett, C. (2010). Refutation Text In Science Education: A Review Of Two Decades Of Research (Vol. 8). https://doi.org/10.1007/s10763-010-9203-x

Tjernström, E., \& Totenberg, T. (2008). Do differences in attitudes explain differences in national climate change policies? Ecological Economics, 65(2), 315-324. https://doi.org/10.1016/j.ecolecon.2007.06.019

Tobler, C., Visschers, V. H. \& Siegrist, M. (2012). Consumers' Knowledge About Climate Change. Climatic Change 114 (2), 189-209.

Toll, R. S. J. (2014). Quantifying the consensus on anthropogenic global warming in the literature: A reanalysis. Energy Policy, 73, 701-705. https://doi.org/10.1016/j.enpol.2014.04.045

Tranter, B. (2011). Political divisions over climate change and environmental issues in Australia. Environmental Politics, 20(1), 78-96. https://doi.org/10.1080/09644016.2011.538167

Tranter, B., \& Booth, K. (2015). Skepticism in a changing climate: A cross-national study. Global Environmental Change, 33(Supplement C), 154-164. https://doi.org/10.1016/j.gloenvcha.2015.05.003

Unsworth, K. L., \& Fielding, K. S. (2014). It's political: How the salience of one's political identity changes climate change beliefs and policy support. Global Environmental Change, 27(Supplement C), 131-137. https://doi.org/10.1016/j.gloenvcha.2014.05.002

USGCRP, 2017: Climate Science Special Report: Fourth National Climate Assessment, (Vol.) 1 [Wuebbles, D.J., D.W. Fahey, K.A. Hibbard, D.J. Dicken, B.C. Stewart, and T.K. Haycock (eds.)]. U.S. 
Global Change Research Program, Washington, DC, USA, 470 pp., doe: 10.7930/J0J964J6.

Viscus, W. K., \& Deckhouse, R. J. (2006). The Perception and Valuation of the Risks of Climate Change: A Rational and Behavioral Blend. Climatic Change, 77(1-2), 151-177. https://doi.org/10.1007/s10584-006-9075-9

Webb, B. S., \& Hayhow, D. (2017). Assessing the Influence of an Educational Presentation on Climate Change Beliefs at an Evangelical Christian College. Journal of Geoscience Education, 65(3), $272-282$.

Weber, E. U., \& Stern, P. C. (2011). Public understanding of climate change in the United States. American Psychologist, 66(4), 315-328. https://doi.org/10.1037/a0023253

Wuebbles, D.J., D.W. Fahey, K.A. Hibbard, B. Deangelo, S. Doherty, K. Hayhow, R. Horton, J.P. Koussin, P.C. Taylor, A.M. Wale, and C.P. Weaver, 2017: Executive summary. In: Climate Science Special Report: Fourth National Climate Assessment, Volume I [Wuebbles, D.J., D.W. Fahey, K.A. Hibbard, D.J. Dicken, B.C. Stewart, and T.K. Haycock (eds.)]. U.S. Global Change Research Program, Washington, DC, USA, pp.12-34, doe: 10.7930/J0DJ5CTG. 
Appendix A. Complete list of survey questions.

\begin{tabular}{|c|c|c|}
\hline \multicolumn{3}{|r|}{ Pre-Survey } \\
\hline $\begin{array}{l}\text { Question } \\
\text { Number }\end{array}$ & Question & Answer Choices \\
\hline 1 & $\begin{array}{l}\text { How important is the issue of } \\
\text { climate change to you? }\end{array}$ & $\begin{array}{l}\text { 7- Very important, 6- Important, 5- Moderately important, } \\
\text { 4- Not sure, 3- Moderately unimportant, 2- Of little } \\
\text { importance, 1- Unimportant }\end{array}$ \\
\hline 2 & $\begin{array}{l}\text { To what degree are you } \\
\text { aware of potential local } \\
\text { impacts of climate change on } \\
\text { biodiversity? }\end{array}$ & $\begin{array}{c}\text { 7- Extremely aware, 6- Moderately aware, 5- Somewhat } \\
\text { aware, 4- Unsure, 3- Somewhat unaware, 2- Moderately } \\
\text { unaware, 1- Extremely unaware }\end{array}$ \\
\hline 3 & $\begin{array}{l}\text { How concerned are you that } \\
\text { local animal and plant species } \\
\text { may be threatened to become } \\
\text { extinct }\end{array}$ & $\begin{array}{l}\text { 7- Very concerned, 6- Moderately concerned, 5- Somewhat } \\
\text { concerned, 4- Unsure, 3- Somewhat unconcerned } \\
\text { 2-Moderately unconcerned, 1- Not at all concerned }\end{array}$ \\
\hline 4 & $\begin{array}{l}\text { How concerned are you that } \\
\text { your outdoor activities may } \\
\text { be threatened by climate } \\
\text { change? }\end{array}$ & $\begin{array}{l}\text { 7- Very concerned, 6- Moderately concerned, 5- Somewhat } \\
\text { concerned, 4- Unsure, 3- Somewhat unconcerned, } \\
\text { 2-Moderately unconcerned, 1- Not at all concerned }\end{array}$ \\
\hline 5 & $\begin{array}{l}\text { I am uncertain that climate } \\
\text { change is occurring }\end{array}$ & $\begin{array}{c}\text { 1- Strongly agree, 2- Agree, 3- Somewhat agree, 4- Neither } \\
\text { agree nor disagree, 5- Somewhat disagree, } \\
\text { 6- Disagree, } 7 \text { - Strongly disagree }\end{array}$ \\
\hline 6 & $\begin{array}{l}\text { I believe that there is still } \\
\text { plenty of time to prepare for } \\
\text { climate change }\end{array}$ & $\begin{array}{c}\text { 1- Strongly agree, 2- Agree, 3- Somewhat agree, 4- Neither } \\
\text { agree nor disagree, 5- Somewhat disagree, 6- Disagree, } \\
\text { 7- Strongly disagree }\end{array}$ \\
\hline 7 & $\begin{array}{l}\text { The effects of global climate } \\
\text { change have not yet begun }\end{array}$ & $\begin{array}{c}\text { 1- Strongly agree, 2- Agree, 3- Somewhat agree, 4- Neither } \\
\text { agree nor disagree, 5- Somewhat disagree, 6- Disagree, } \\
\text { 7- Strongly disagree }\end{array}$ \\
\hline 8 & $\begin{array}{l}\text { I believe climate change will } \\
\text { affect me personally }\end{array}$ & $\begin{array}{c}\text { 7- Strongly agree, 6- Agree, 5- Somewhat agree, 4- Neither } \\
\text { agree nor disagree, 3- Somewhat disagree, 2- Disagree, } \\
\text { 1- Strongly disagree }\end{array}$ \\
\hline 9 & $\begin{array}{l}\text { I am not concerned about } \\
\text { water supply in the region I } \\
\text { live in }\end{array}$ & $\begin{array}{c}\text { 1- Strongly agree, 2- Agree, 3- Somewhat agree, 4- Neither } \\
\text { agree nor disagree, 5- Somewhat disagree, 6- Disagree, } \\
\text { 7- Strongly disagree }\end{array}$ \\
\hline 10 & $\begin{array}{l}\text { Human-induced global } \\
\text { climate change is widely } \\
\text { accepted by most of the } \\
\text { scientific community }\end{array}$ & $\begin{array}{c}\text { 7- Strongly agree, 6- Agree, 5- Somewhat agree, 4- Neither } \\
\text { agree nor disagree, 3- Somewhat disagree, 2- Disagree, } \\
\text { 1- Strongly disagree }\end{array}$ \\
\hline 11 & $\begin{array}{l}\text { I believe the effects of } \\
\text { climate change have already } \\
\text { begun }\end{array}$ & $\begin{array}{c}\text { 7- Strongly agree, 6- Agree, 5- Somewhat agree, 4- Neither } \\
\text { agree nor disagree, 3- Somewhat disagree, 2- Disagree, } \\
\text { 1- Strongly disagree }\end{array}$ \\
\hline 12 & $\begin{array}{l}\text { I believe the majority of } \\
\text { global climate change is } \\
\text { occurring by human activities }\end{array}$ & $\begin{array}{c}\text { 7- Strongly agree, 6- Agree, 5- Somewhat agree, 4- Neither } \\
\text { agree nor disagree, } 3 \text { - Somewhat disagree, 2- Disagree, } \\
\text { 1- Strongly disagree }\end{array}$ \\
\hline
\end{tabular}




\begin{tabular}{|c|l|c|}
\hline 13 & $\begin{array}{l}\text { I believe there is not enough } \\
\text { time to prepare for climate } \\
\text { change }\end{array}$ & $\begin{array}{c}\text { 7- Strongly agree, 6- Agree, 5- Somewhat agree, 4- Neither } \\
\text { agree nor disagree, 3- Somewhat disagree, 2- Disagree, } \\
\text { 1- Strongly disagree }\end{array}$ \\
\hline 14 & $\begin{array}{l}\text { Climate change will not } \\
\text { affect me personally }\end{array}$ & $\begin{array}{r}\text { 1- Strongly agree, 2- Agree, 3- Somewhat agree, 4- Neither } \\
\text { agree nor disagree, 5- Somewhat disagree, 6- Disagree, } \\
\text { 7- Strongly disagree }\end{array}$ \\
\hline 15 & $\begin{array}{l}\text { I am concerned about water } \\
\text { supply and availability in my } \\
\text { region }\end{array}$ & $\begin{array}{c}\text { 7- Strongly agree, 6- Agree, 5- Somewhat agree, 4- Neither } \\
\text { agree nor disagree, 3- Somewhat disagree, 2- Disagree, } \\
\text { 1- Strongly disagree }\end{array}$ \\
\hline \multirow{2}{*}{$\begin{array}{l}\text { I believe the majority of } \\
\text { global climate change is } \\
\text { occurring by natural changes } \\
\text { in the environment }\end{array}$} & $\begin{array}{l}\text { 1- Strongly agree, 2- Agree, 3- Somewhat agree, 4- Neither } \\
\text { agree nor disagree, 5- Somewhat disagree, 6- Disagree, } \\
\text { 7- Strongly disagree }\end{array}$ \\
\hline 17 & $\begin{array}{l}\text { 1- Strongly agree, 2- Agree, 3- Somewhat agree, 4- Neither } \\
\text { agree nor disagree, 5- Somewhat disagree, 6- Disagree, } \\
\text { 7- Strongly disagree }\end{array}$ \\
\hline
\end{tabular}


Post-Survey

\begin{tabular}{|c|c|c|}
\hline $\begin{array}{l}\text { Question } \\
\text { Number }\end{array}$ & Question & Answer Choices \\
\hline 1 & $\begin{array}{l}\text { I am more alarmed } \\
\text { about climate change } \\
\text { than when I started this } \\
\text { activity }\end{array}$ & $\begin{array}{c}\text { 7- Strongly agree, 6- Agree, 5- Somewhat agree, 4- Neither agree } \\
\text { nor disagree, 3- Somewhat disagree, 2- Disagree, 1- Strongly } \\
\text { disagree }\end{array}$ \\
\hline 2 & $\begin{array}{l}\text { Climate change will } \\
\text { pose a threat to me or } \\
\text { my way of life in my } \\
\text { lifetime }\end{array}$ & $\begin{array}{c}\text { 7- Strongly agree, 6- Agree, 5- Somewhat agree, 4- Neither agree } \\
\text { nor disagree, 3- Somewhat disagree, 2- Disagree, 1- Strongly } \\
\text { disagree }\end{array}$ \\
\hline 3 & $\begin{array}{l}\text { I am not concerned } \\
\text { about water supply in } \\
\text { my region }\end{array}$ & $\begin{array}{c}\text { 1- Strongly agree, 2- Agree, 3- Somewhat agree, 4- Neither agree } \\
\text { nor disagree, 5- Somewhat disagree, 6- Disagree, 7- Strongly } \\
\text { disagree }\end{array}$ \\
\hline 4 & $\begin{array}{l}\text { I believe the majority } \\
\text { of global climate } \\
\text { change is occurring by } \\
\text { natural changes in the } \\
\text { environment }\end{array}$ & $\begin{array}{c}\text { 1- Strongly agree, 2- Agree, 3- Somewhat agree, 4- Neither agree } \\
\text { nor disagree, 5- Somewhat disagree, 6- Disagree, 7- Strongly } \\
\text { disagree }\end{array}$ \\
\hline 5 & $\begin{array}{l}\text { Climate change will not } \\
\text { pose a threat to me or } \\
\text { my way of life in my } \\
\text { lifetime }\end{array}$ & $\begin{array}{c}\text { 1- Strongly agree, 2- Agree, 3- Somewhat agree, 4- Neither agree } \\
\text { nor disagree, 5- Somewhat disagree, 6- Disagree, 7- Strongly } \\
\text { disagree }\end{array}$ \\
\hline 6 & $\begin{array}{l}\text { I believe the majority } \\
\text { of global climate } \\
\text { change is occurring by } \\
\text { human activities }\end{array}$ & $\begin{array}{c}\text { 7- Strongly agree, 6- Agree, 5- Somewhat agree, 4- Neither agree } \\
\text { nor disagree, 3- Somewhat disagree, 2- Disagree, 1- Strongly } \\
\text { disagree }\end{array}$ \\
\hline 7 & $\begin{array}{l}\text { The seriousness of } \\
\text { climate change is } \\
\text { exaggerated }\end{array}$ & $\begin{array}{c}\text { 1- Strongly agree, 2- Agree, 3- Somewhat agree, 4- Neither agree } \\
\text { nor disagree, 5- Somewhat disagree, 6- Disagree, } 7 \text { - Strongly } \\
\text { disagree }\end{array}$ \\
\hline 8 & $\begin{array}{l}\text { I am more concerned } \\
\text { about water supply and } \\
\text { availability in my } \\
\text { region. }\end{array}$ & $\begin{array}{c}\text { 7- Strongly agree, 6- Agree, 5- Somewhat agree, 4- Neither agree } \\
\text { nor disagree, 3- Somewhat disagree, 2- Disagree, 1- Strongly } \\
\text { disagree }\end{array}$ \\
\hline 9 & $\begin{array}{l}\text { I am more aware of } \\
\text { how climate change } \\
\text { will affect me } \\
\text { personally }\end{array}$ & $\begin{array}{c}\text { 7- Strongly agree, 6- Agree, 5- Somewhat agree, 4- Neither agree } \\
\text { nor disagree, 3- Somewhat disagree, 2- Disagree, 1- Strongly } \\
\text { disagree }\end{array}$ \\
\hline 10 & $\begin{array}{l}\text { I am concerned about } \\
\text { how global climate } \\
\text { change will affect my } \\
\text { outdoor activities }\end{array}$ & $\begin{array}{c}\text { 7- Strongly agree, 6- Agree, 5- Somewhat agree, 4- Neither agree } \\
\text { nor disagree, 3- Somewhat disagree, 2- Disagree, 1- Strongly } \\
\text { disagree }\end{array}$ \\
\hline 11 & $\begin{array}{l}\text { To what degree are you } \\
\text { now aware of potential } \\
\text { local impacts of climate } \\
\text { change on biodiversity? }\end{array}$ & $\begin{array}{c}\text { 7- Extremely aware, 6- Moderately aware, 5- Somewhat aware, } \\
\text { 4- Unsure, 3- Somewhat unaware, 2- Moderately unaware, } \\
\text { 1- Extremely unaware }\end{array}$ \\
\hline 12 & $\begin{array}{l}\text { In general, do you think } \\
\text { that a rise in the world's } \\
\text { temperature caused by } \\
\text { the "greenhouse effect" }\end{array}$ & $\begin{array}{c}\text { 7- Extremely dangerous, 6- Very dangerous, 5- Somewhat } \\
\text { dangerous 4- Unsure, 3- Somewhat not dangerous, 2- Not very } \\
\text { dangerous, 1- Not at all dangerous }\end{array}$ \\
\hline
\end{tabular}




\begin{tabular}{|c|c|c|}
\hline & $\begin{array}{l}\text { is dangerous to the } \\
\text { environment? }\end{array}$ & \\
\hline 13 & $\begin{array}{l}\text { To what extent are you } \\
\text { willing to take personal } \\
\text { action to reduce your } \\
\text { own carbon emissions? }\end{array}$ & $\begin{array}{l}\text { 1- Extremely unwilling, 2- Moderately unwilling, 3- Somewhat } \\
\text { unwilling, 4- Neither unwilling nor willing, 3- Somewhat willing, } \\
\text { 2- Moderately willing, 1- Extremely willing }\end{array}$ \\
\hline 14 & $\begin{array}{l}\text { How convinced are you } \\
\text { that climate change is } \\
\text { actually happening- } \\
\text { would say that you are }\end{array}$ & $\begin{array}{c}\text { 7- Was already convinced, 6- Completely convinced, 5- Mostly } \\
\text { convinced, 4- Unsure, 3- Mostly unconvinced, 2-Completely } \\
\text { unconvinced, 1- Not convinced at all }\end{array}$ \\
\hline 15 & $\begin{array}{l}\text { When it comes to the } \\
\text { issue of global climate } \\
\text { change, how well do } \\
\text { you feel you } \\
\text { understand this }\end{array}$ & $\begin{array}{l}\text { 7- Understood it very well, 6- Understood most of it, } \\
\text { 5- Moderately well, 4- Not sure, 3- Understood a little, 2- Not } \\
\text { very well, 1- Did not understand }\end{array}$ \\
\hline
\end{tabular}


Appendix B. Tables for demographic variables.

Table 4.2. Change in concern level and gender given in percentages

\begin{tabular}{|l|r|r|r|}
\hline Gender & Increase & \multicolumn{2}{|c|}{ Decrease } \\
Female & $22.3 \%$ & $19.4 \%$ & $58.3 \%$ \\
\hline Male & $30.0 \%$ & $25.0 \%$ & $45.0 \%$ \\
\hline
\end{tabular}

Table 4.3. Change in concern and ethnicity given in percentages

\begin{tabular}{|l|r|r|r|} 
Ethnicity & \multicolumn{2}{c|}{ Decrease } & \multicolumn{2}{c|}{ No Change } \\
\hline Hispanic & $26.5 \%$ & $24.5 \%$ & $49.0 \%$ \\
\hline Non-Hispanic & $28.6 \%$ & $14.3 \%$ & $57.1 \%$ \\
\hline
\end{tabular}

Table 4.4. Change in climate change concern level disaggregated by gender and ethnicity

\begin{tabular}{|l|r|r|r|}
\hline Gender/Ethnicity & Increase & $21.7 \%$ & Nocrease change \\
\hline Female/Hispanic & $21.7 \%$ & $15.4 \%$ & $56.6 \%$ \\
\hline Female/Non-Hispanic & $23.1 \%$ & $26.9 \%$ & $61.5 \%$ \\
\hline Male/Hispanic & $30.8 \%$ & $21.4 \%$ & $52.3 \%$ \\
\hline Male/Non-Hispanic & $28.6 \%$ & $50.0 \%$ \\
\hline
\end{tabular}

Table 4.5. Change in concern and political view. Missing values indicate there was no participants for that political view

\begin{tabular}{|l|r|r|r|}
\hline Political View & Increase & Decrease & \multicolumn{2}{c|}{ No Change } \\
\hline Liberal & $13.3 \%$ & $33.3 \%$ & $53.4 \%$ \\
\hline Moderate & $27.3 \%$ & $27.3 \%$ & $45.4 \%$ \\
\hline Conservative & $36.8 \%$ & $21.1 \%$ & $42.1 \%$ \\
\hline Rather Not Say & & $33.3 \%$ & $66.7 \%$ \\
\hline Not Sure & $35.7 \%$ & & $64.3 \%$ \\
\hline
\end{tabular}


Table 4.6. Concern level and education level. Missing values indicate there were no participants of that age group or concern level

\begin{tabular}{|c|c|c|c|}
\hline Education Level & Increase & Decrease & No Change \\
\hline Some High School or Less & $50.0 \%$ & & $50.0 \%$ \\
\hline High School & $41.7 \%$ & $16.6 \%$ & $41.7 \%$ \\
\hline Some College & $27.8 \%$ & $27.8 \%$ & $44.4 \%$ \\
\hline Bachelor's & $23.5 \%$ & $35.3 \%$ & $41.2 \%$ \\
\hline Some Graduate & $25.0 \%$ & & $75.0 \%$ \\
\hline Master's & $22.2 \%$ & $22.2 \%$ & $55.6 \%$ \\
\hline Doctorate & & & $100.0 \%$ \\
\hline Other & & & $100.0 \%$ \\
\hline
\end{tabular}




\section{Vita}

My name is Ivy Gisselle Trevizo and I attended Wayland Baptist University where I received a Bachelor's of Science in 2011. As an undergraduate student, I worked on a research project titled Experimental test of the Function of Rock Wren Nest Pavement. In 2012, I participated in an internship at Au Sable Institute of Environmental Studies where I was an Environmental Education Intern and taught Natural Science and Michigan History to K-12 grade students. In 2015, I participated in Upward Bound Summer Camp where I helped lead a UTEP Earth Tech summer camp for high school students. This program is a part of a year-round college preparatory program for students from low-income families. I helped lead science programs such as water sampling and testing, mapping and led field trips to Hueco Tanks and the Water Treatment plant. I also participated in the Diana Natalicio internship at the USDASouthwest Climate Hub in Summer of 2017. I was tasked with creating a presentation on the mistakes scientists make when communicating climate change. I also worked on a Climate Masters project with a goal of creating a volunteer culture of Climate Masters to increase climate literacy and support both adaptation and mitigation activities. I have held the job of a substitute teacher since 2014 at the Socorro Independent School District where I provide classroom instruction for K- $8^{\text {th }}$ grade students. I am also a volunteer at the Franklin Mountain Sate Park and help lead hikes.

Contact Information: ivy.trevizo@yahoo.com

This thesis/dissertation was typed by Ivy G. Trevizo 